\title{
Risk Sharing and Industrial Specialization: Regional and International Evidence*
}

\author{
Sebnem Kalemli-Ozcan \\ Brown University
}

\author{
Bent E. Sørensen \\ Brown University
}

April 1999

\author{
Oved Yosha \\ Tel Aviv University
}

\begin{abstract}
We provide empirical evidence that risk sharing enhances specialization in production. To the best of our knowledge, this well-established and important theoretical proposition has not been tested before. Our empirical procedure is summarized as follows. First, we construct a measure of specialization in production, and calculate an index of specialization for each of the European Community (EC) and non-EC OECD countries, U.S. states, Canadian provinces, Japanese prefectures, Latin American countries, and regions of Italy, Spain, and the United Kingdom. Then, we estimate the degree of capital market integration (a measure of risk sharing) within each of these groups of regions: the EC countries, the non-EC OECD countries, the United States, Canada, Japan, Italy, Spain, and the United Kingdom (and rely on another author's estimate for Latin America). Finally, we perform a regression of the specialization index on the degree of risk sharing, controlling for relevant economic variables. We find a positive and significant relation between the degree of specialization of individual members of a group of countries, provinces, states, or prefectures, and the amount of risk that is shared within the group. We perform regressions using variables such as shareholder rights and the size of the financial sector (relative to GDP) as instruments for the amount of inter-regional risk sharing. These regressions confirm that risk sharing - facilitated by a favorable legal environment and a developed financial system-is a direct causal determinant of industrial specialization.
\end{abstract}

JEL Classification: F15, F2, F36, F43

${ }^{*}$ We thank Charles Kroll, Elena Krop, and in particular, Lauren Sella for research assistance as well as Jacques Mélitz, Frédéric Zumer, and Maria Luengo-Prado for help with the Italian and Spanish data, respectively. Elise Brezis, Jess Gaspar, Elhanan Helpman, Pravin Krishna, Eric van Wincoop, and participants at seminars at Albany, Arizona State, Bank of Israel, Bar Ilan, Birkbeck, Brown, CEMFI, DELTA, ECARE, Haifa, Kansas City Federal Reserve, LSE, New York Federal Reserve, Rochester, Royal Holloway, Rutgers, Tel Aviv, Toulouse, Vanderbilt, at the 1999 North American Winter Meetings of the Econometric Society, and in a conference on Risk Sharing and Economic Vulnerability at the Joint Center for Poverty Research, University of Chicago and Northwestern University, provided helpful comments and suggestions. 


\section{Introduction}

That countries gain from specialization is one of the few widely accepted economic tenets. Gains from specialization may arise from technological differences (Ricardo), factor endowments (Heckscher-Ohlin), or from increasing returns to scale. ${ }^{1}$ These theories have traditionally been formulated in non-stochastic environments. In the presence of production risk and in the absence of markets for insuring this risk, countries that specialize in the production of a small number of goods may suffer a loss in economic welfare due to the high variance of Gross Domestic Product (GDP). These countries may therefore choose not to specialize, as noted by Brainard and Cooper (1968), Kemp and Liviatan (1973), and Ruffin (1974).

Insurance of production risk may take many forms, from explicit insurance against adverse outcomes (typically natural disasters) to forward markets where commodities are sold at a fixed price for future delivery. The main mechanism for spreading risk among regions and countries is, however, diversification of ownership, achieved via capital markets. If interregional and international capital markets are well integrated, regions and countries, being insured against idiosyncratic shocks, can afford to specialize more thereby exploiting comparative advantage further, whether such advantage is due to technology, factor endowments, or economies of scale. Indeed, from the analysis in Helpman and Razin (1978a, 1978b) it follows that country specialization will be higher when there is international trade in both securities and goods. ${ }^{2}$ Helpman and Razin's analysis covers both the Ricardian case (without insurance, countries may not fully specialize in the good they can produce at low unit cost), and the Heckscher-Ohlin case (without insurance, countries will specialize less in the good that is intensive in the factor in which they are relatively abundant), but does not address the case of trade driven by increasing returns to scale. A simple example provided in the next section illustrates how their proposition applies to this case as well.

Insurance induced specialization has potentially non-trivial consequences for economic growth. Greenwood and Jovanovic (1990), Saint-Paul (1992), Obstfeld (1994a), Acemoglu and Zilibotti (1997), and Feeney (1997) have written theoretical models where capital market integration induces higher specialization which in turn stimulates output and growth. In Obstfeld (1994a) the basic premise is that countries choose the investment mix in risky (high

\footnotetext{
${ }^{1}$ See, e.g., Krugman (1979) and Helpman (1981, 1984).

${ }^{2}$ Further work on this topic include papers by Anderson (1981), Grossman and Razin (1984, 1985), Helpman (1988), and Feeney (1994).
} 
return) projects and safe (low return) projects. International asset trade allows countries to hold a diversified portfolio encouraging them to shift investment towards high return projects. ${ }^{3}$ In the model proposed by Saint-Paul (1992), the basic trade-off is between the gains from specialization due to comparative advantage in production and a lower variance of output, while Feeney (1997) develops the idea that in the presence of learning by doing in production, an increase in specialization entails higher growth during a transition period.

To the best of our knowledge, no evidence has been brought to bear on this issue. Hufbauer and Chilas (1974) and Krugman (1991) demonstrated that U.S. states are more specialized than OECD countries, and interpreted this observation as evidence that barriers to trade are greater across countries than across U.S. states, but neither performed a systematic empirical study of the determinants of regional specialization patterns - a task we undertake here.

Researchers (see King and Levine (1993), Levine and Zervos (1998), and Rajan and Zingales (1998) for prominent examples) have found a positive correlation between "financial depth" and the rate of economic growth. They have not, however, provided direct evidence regarding the mechanism through which financial intermediation and capital market integration promote growth. One such mechanism is higher specialization in production facilitated by better spreading of production risk which, in turn, is more easily achieved where financial markets are developed and reliable. Our empirical results provide strong support for this view.

The theoretical models described above point to the following empirical strategy: For various groups of regions or countries (e.g., U.S. states, Japanese prefectures, European Community (EC) countries), calculate a measure of the degree of insurance among members of the group, and for each member compute an index of industrial specialization in production. Then, to test the common empirical prediction of the above theories, check whether a high degree of insurance (risk sharing) within a group of regions or countries is associated with high specialization in production of the group members, when other potential determinants of industrial specialization are controlled for. Next, find variables which are exogenous to the degree of specialization but likely to be correlated with the extent of observed inter-regional risk sharing, and perform instrumental variables regression in order to determine the direction

\footnotetext{
${ }^{3}$ A similar trade-off is modeled in Acemoglu and Zilibotti (1997) who stress the fact that developing countries have less diversification opportunities in production and therefore tend to specialize in safe technologies. In Greenwood and Jovanovic (1990), financial intermediaries pool risks and help achieve higher and safer returns on investment.
} 
of causality.

Much of the variation in our sample is due to differences in risk sharing and specialization across groups of regions that constitute countries (U.S. states, Canadian provinces, and so forth), but the basic logic of our approach is best illustrated by the striking difference in patterns of risk sharing and specialization in groups of regions within countries versus groups of countries.

It is, by now, a well established empirical regularity that there is little risk sharing between countries; see French and Poterba (1991) and Tesar and Werner (1995) who document the "home bias" puzzle, Backus, Kehoe, and Kydland (1992) who compare cross-country GDP correlations and consumption correlations, and Sørensen and Yosha (1998) and Arreaza (1998) who carry out cross-country variance decompositions of shocks to GDP for EC/OECD and Latin American countries respectively. All these studies point to negligible risk sharing through cross-country ownership of assets.

In contrast, as shown by Asdrubali, Sørensen, and Yosha (1996), there is substantial risk sharing among states within the United States. Using the same methodology, Alberola and Asdrubali (1998) and Dedola, Usai, and Vannini (1998) found substantial risk sharing among regions within Italy, Spain, and the United Kingdom. In this paper we further document considerable risk sharing among provinces within Canada and among prefectures within Japan. ${ }^{4}$ If risk sharing is important for specialization one would expect U.S. states, regions of Spain, Italy, and the United Kingdom, Canadian provinces, and Japanese prefectures to be more specialized than EC, OECD, or Latin American countries. Our empirical work confirms this hypothesis.

The finding survives when we perform a more detailed regression analysis with the approximately 170 regions and countries in our sample, controlling for characteristics such as population density and per capita GDP, and using various measures of specialization and various sub-samples (e.g., omitting U.S. states or Latin American countries from the sample).

Finally, and perhaps most important, the positive relation between risk sharing and specialization also survives when we perform the regressions only with regions within countries (i.e., eliminating groups of countries from the sample). This confirms that the differences in

\footnotetext{
${ }^{4}$ Other work on inter-regional risk sharing includes Crucini (1999), Athanasoulis and van Wincoop (1998), del Negro (1998), and Hess and Shin (1998).
} 
specialization patterns are not (entirely) driven by differences in the amount and composition of, or barriers to, international versus intranational trade. It also suggests that the results are not driven by higher factor (physical capital or labor) mobility across regions within countries than across countries.

Exogeneity of inter-regional risk sharing through cross-holding of productive assets-the central explanatory variable of specialization in our empirical specification-is an issue of importance. In all the theoretical models cited above, insurance among economic agents is regarded as exogenous. To justify this assumption, one may invoke the exogeneity of institutions that allow agents to insure. Decisions regarding the choice of product lines, entry to an industry, or investment in new technologies are taken by firm managers and shareholders and by entrepreneurs who take insurance opportunities as given. Even if these institutions change over time, the change is slow and does not affect the decision to specialize in production.

Although this view has merit, it is wise to allow for a different scenario, where the degree of inter-regional cross-holding of productive assets is affected-at least to some extent-by the degree of specialization in production. One might imagine, for example, a federation with geographic or demographic characteristics that render high regional specialization particularly attractive. Institutions that facilitate risk sharing may then develop in response to the need for insurance raised by the specialized regional production structure. In order to obtain estimates that are robust to such "reverse causality," we use instrumental variables estimation. Fortunately, instruments are available that are highly unlikely to be affected by reverse causality. In particular, we use quantitative indicators of the strength of the part of the "legal environment," for instance protection of investor rights, that is likely to have an impact on the amount of cross-regional ownership. In the corporate finance literature it has been documented that the legal tradition - as it impacts on, shareholder rights for exampleis a strong determinant of national stock market capitalization (the premier institution for nationwide risk sharing). We use the legal environment indicators suggested by La Porta et al. $(1997,1998)$ as instruments. We further use the share of the financial sector in GDP-a direct indicator of "financial depth" —as an alternative instrument. Our results are not sensitive to what instruments we use and are similar to the OLS results, which indicates that, to a first approximation, risk sharing is exogenous for specialization and causality runs from risk sharing to specialization.

Constructing measures of industrial specialization in production is standard. By contrast, 
measuring the amount of risk sharing achieved within a group of regions or countries is not. A central methodological issue in this context is whether we should construct a measure of the extent to which regions smooth their income (for example, through cross-regional diversification of ownership) or, whether we should use a measure of the smoothness of regional consumption. We discuss conceptual aspects of this choice at the end of the next section. For our main specification, we opt for an income-based measure of risk sharing, but in a separate section, we also study empirically the relation between industrial specialization and a consumption-based measure of risk sharing.

In Section 2, we spell out a simple framework that highlights the effect of risk sharing on specialization and addresses conceptual aspects concerning the measurement of risk sharing and specialization. In Section 3, we describe the specialization and risk sharing measures that we use in our analysis. The empirical results are presented in Section 4 . Section 5 is devoted to the analysis of a consumption-based measure of risk sharing, Section 6 concludes, and an appendix describes our data.

\section{A Simple Conceptual Framework}

The theoretical foundations for the effect of risk sharing on industrial specialization are well established, so we do not see a need for a detailed model. It is, nevertheless, helpful to reformulate the theory in our own words to set the stage for the empirical analysis. Being novel, the empirical implementation of the theory poses conceptual difficulties that are best addressed with a stylized model in the background. We present a variant of the theory relating risk sharing and specialization that has not been studied before (although it is a straightforward adaptation of existing models) where "comparative advantage" is a result only of increasing returns to scale in production.

Consider a "risk sharing group" consisting of several regions of equal size. ${ }^{5}$ The regions could be states or prefectures within a country, countries within the OECD, and so forth. Consumers in each region are risk averse. There is one consumption good that can be produced with inelastically supplied labor and no fixed costs, using any of several ex-ante identical technologies, all exhibiting decreasing marginal costs (increasing returns to scale) and all subject to identically distributed and imperfectly correlated productivity shocks that

\footnotetext{
${ }^{5}$ The basic logic does not rely on this or on most other simplifying assumptions that we make in this section.
} 
are specific to each technology. ${ }^{6}$ For simplicity, assume that there is no aggregate uncertainty, in the sense that there are no shocks that are common to all technologies, namely, by producing with equal use of all the technologies, every region can eliminate GDP variability altogether.

Every region can produce the consumption good with any of the available technologies. The choice of how many technologies to use depends on the trade-off between the desire to take advantage of increasing returns in production on the one hand, and the gains from diversifying the productivity shocks across technologies on the other. We assume that consumers are very risk averse (or, alternatively, that the productivity shocks are very violent) so that, absent mechanisms for smoothing these shocks, every region will choose to produce with all (or most) available technologies.

Cross-regional insurance markets constitute a central mechanism for smoothing idiosyncratic regional shocks. When citizens in one region hold debt or equity claims (directly or through intermediaries) to the output flow of productive assets in other regions, the dividend, interest, and rental income derived from these holdings help smooth the income of all the regions. A second channel for smoothing shocks is borrowing and lending on inter-regional credit markets or, more generally, saving and dis-saving in response to shocks. Such behavior amounts to adjustment of the wealth portfolio, including sale and purchase of assets.

The first mechanism, ex-ante inter-regional insurance, is effective for smoothing all types of shocks, both permanent and transitory. To illustrate, if in a given year a severe natural disaster hits the state of Florida, drastically reducing Florida's gross product, the income of Florida's inhabitants will not go down by as much since many of them obtain interest and dividend income from out-of-state sources (e.g., investment funds and savings accounts). This is true regardless of the persistence of the shock to Florida's economy.

The second mechanism, ex-post adjustment of asset portfolios, can be used to smooth only transitory shocks. If a negative shock to the income of a region is perceived as temporary, the region's inhabitants will want to borrow (or sell assets) in order to smooth their consumption. By contrast, a persistent shock to income i.e., a persistent uninsured shock to GDP) will not be smoothed, as we know from permanent income theory. Thus, regions without insurance that are hit by permanent shocks will adjust their (permanent) consumption

\footnotetext{
${ }^{6}$ This simplifying assumption ensures that there will be full specialization in the special case of complete markets and an equal number of technologies and regions, as will be explained shortly. The assumption is by no means necessary for the basic logic to hold.
} 
level accordingly. We return to this crucial distinction between ex-ante income smoothing and ex-post consumption smoothing mechanisms shortly. For now, we concentrate on the first mechanism, cross-regional insurance that, in our view, is closest in spirit to the above cited theories that motivate our empirical investigation.

Suppose that perfect (Pareto efficient) cross-regional insurance is available. In this section, we do not distinguish between insurance obtained via markets or via central fiscal institutions (for instance, through taxes and transfers or government aid), but in the empirical implementation we will regard these as separate channels of cross-regional insurance.

For simplicity, assume that there are as many technologies as regions. Then, under full risk sharing, each region will specialize in one technology in order to fully exploit the economies of scale in production. Furthermore, each region will specialize in a different technology so that the gains from diversification are maximized within the risk sharing group. Given our assumption of no aggregate risk, the total GDP of the risk sharing group (and hence, the income and consumption in every region of the group) will be non-stochastic.

Suppose that only partial cross-regional insurance is possible (and that ex-post smoothing of consumption is not feasible, either because shocks are highly persistent or due to credit market imperfections). It is reasonable to expect a positive association between the degree of cross-regional insurance and the extent of specialization in production (where higher specialization means that fewer technologies are used in each region). Obtaining such a result formally requires a specific model and an explicit definition of what is meant by partial insurance. Since our focus is empirical, we choose not to engage in such modeling. Our goal in this section is simply to illustrate the relevance of the Helpman and Razin (1978a, 1978b) analysis for the increasing returns case (with no comparative advantage due to differences in technology or endowments).

Some remarks are in order. In the above example, there are as many technologies as regions. If insurance markets are complete, full regional specialization in production is equivalent to full localization (or concentration) of production-each technology is used in exactly one region. This suggests that the specialization patterns of regions and the regional concentration of production are strongly related. Yet, as the following example illustrates, these are distinct concepts. Suppose that there are more technologies than regions (the more realistic case). If risk aversion is sufficiently strong, then even if cross-regional insurance is feasible, regions may use more than one technology-otherwise there would be unexploited gains from diversification that may exceed forgone benefits from economies of scale. Thus, 
although production may be fully concentrated, with every technology being used in exactly one region, specialization in production is not full. In this paper, we focus solely on the issue of regional specialization in production, on which the above cited theoretical studies bear.

An analogous logic holds if the gains from specialization are due to technological comparative advantage, rather than to economies of scale, as in Saint-Paul (1992). It should also be apparent that the one good multi-technology setting is equivalent to a multi-good setting where regions specialize in the production of particular goods rather than in the use of specific technologies. ${ }^{7}$ Since the basic trade-off between diversification and specialization has been modeled extensively in the literature, we believe that there is no need to elaborate further on this intuition.

\section{Choosing a risk sharing measure}

As explained above, if shocks to the economies of regions (and countries) are transitory then, even without insurance, consumption can be smoothed ex-post if necessary. Regions can then afford to specialize regardless of the availability of income insurance. In reality, macroeconomic shocks are highly persistent, and (especially international and inter-regional) credit markets often exhibit imperfections. Anticipating long-lasting shocks that cannot be smoothed ex-post through saving and dis-saving, regions will not specialize unless they have access to insurance. We, therefore, believe that income-based measures of risk sharing are more appropriate for our study.

In reality, regions and countries smooth shocks through both ex-ante insurance of income and ex-post adjustment of saving. ${ }^{8}$ Given the persistent nature of most macroeconomic shocks, ex-post smoothing of consumption cannot be easily explained with standard permanent income theory. This is a manifestation of the well known "excess smoothness puzzle" suggested by Campbell and Deaton (1989). There are many competing explanations of this puzzle, see Deaton (1992), but none is generally accepted. This further suggests that consumption-based measures of risk sharing are less than ideal for our purpose. ${ }^{9}$ For the sake

\footnotetext{
${ }^{7}$ The multi-good setting (with many more goods than regions and preference for variety) probably provides a more realistic explanation of why regions are rarely fully specialized.

${ }^{8}$ This has been documented for U.S. states and OECD countries by Asdrubali, Sørensen, and Yosha (1996) and Sørensen and Yosha (1998), respectively.

${ }^{9}$ The study of Ravallion and Chaudhuri (1997) raises further concerns regarding consumption-based measures of risk sharing. In particular, they stress the point (raised previously by Deaton) that common news about future income affects everyone's current consumption, biasing tests towards non-rejection of the per-
} 
of completeness we report the empirical relation between a consumption-based measure of risk sharing and industrial specialization in Section 5 .

Which risk sharing measure correlates better with specialization depends on how decisions to manufacture certain goods and not others, or to build new plants and close down others, are determined. Such decisions are typically made by managers and entrepreneurs, taking into account a multitude of factors, for example, the cost of raising capital, the skills and education level of the work force, and incentives provided by (local or national) governments. In this paper we do not attempt to relate our results to these potential determinants of specialization patterns. They provide, no doubt, natural topics for further research.

\section{Measuring Specialization and Risk Sharing}

\section{Measuring risk sharing}

We measure the extent to which risk is shared within risk sharing groups. Each group consists of regions within a country, or of countries (in which case we call each country in the group a "region"). The representative consumer of each region is a risk averse maximizer of lifetime expected utility from consumption. If utility functions are CRRA, and all regions have a common intertemporal discount factor, a perfect (Pareto efficient) risk sharing allocation satisfies $x_{i t}=k_{i} X_{t}$ for all $t$ and all realizations of uncertainty, where $x_{i t}$ and $X_{t}$ are generic variables representing regional and aggregate income or consumption. The constant $k_{i}$ is independent of time and "state of the world." It reflects the "power" (including initial wealth) of region $i$ in the risk sharing arrangement. If full risk sharing is achieved via income smoothing, then $x_{i t}$ and $X_{t}$ represent both income and consumption (since, in this case, income equals consumption). If full risk sharing is achieved only after both income and consumption smoothing, (in this case, income does not equal consumption), then $x_{i t}$ and $X_{t}$ represent consumption.

Earlier empirical work on risk sharing took the perfect risk sharing consumption allocation, $c_{i t}=k_{i} C_{t}$, seriously focusing on tests of full (Pareto efficient) risk sharing by asking whether idiosyncratic consumption (of individuals or countries) responds to aggregate fluctuations, but not to idiosyncratic shocks to income or GDP. ${ }^{10}$ These studies do not, however,

fect risk sharing null. Our measures, like most econometric studies of consumption, can not identify news in advance of actual changes in income.

${ }^{10}$ Studies using micro-data include Altug and Miller (1990), Cochrane (1991), Mace (1991), Townsend 
provide a method for quantifying the amount of risk sharing achieved among a group of individuals, regions, or countries. Nor do they distinguish between income smoothing through insurance and consumption smoothing through ex-post adjustment of wealth portfolios.

Asdrubali, Sørensen, and Yosha (1996) fill this gap, measuring the fraction of idiosyncratic GDP shocks absorbed through various channels of cross-regional (or cross-national) insurance, and the fraction of shocks that is not smoothed. They distinguish between income insurance through cross-regional holdings of debt and equity ("capital market income smoothing") and via the super-regional tax-transfer system ("federal government income smoothing"). ${ }^{11}$

We describe, first, their measure of cross-regional insurance via markets, $\beta_{K}$. This measure captures the degree of inter-regional capital market integration, in the sense of cross-holding of assets. The more diversified cross-regional asset holdings are, the less sensitive regional income will be to idiosyncratic (region-specific) GDP shocks. This measure of risk sharing corresponds well with the approach taken by Helpman and Razin (1978a, 1978b) who focus on the relationship between trade in financial assets and specialization in production (trade in goods).

Consider the panel regression (across the regions of a risk sharing group) $\Delta \log \mathrm{PINC}_{i t}=$ $\nu_{t}+\beta_{1} \Delta \log \mathrm{GDP}_{i t}+\epsilon_{i t}$, where $\mathrm{PINC}_{i t}$ is region $i$ 's personal income in year $t$, and $\nu_{t}$ are time fixed effects, namely, the coefficient $\beta_{1}$ measures the co-movement of income with idiosyncratic (region-specific) GDP shocks. The inclusion of time fixed effects is crucial because they capture year specific impacts on the growth in the aggregate GDP of the risk sharing group which cannot be diversified away even under perfect risk sharing within the group. ${ }^{12}$

If income is fully smoothed within the group, the growth rate of each region's personal income would be equal to the growth rate of the group's aggregate personal income, and the coefficient $\beta_{1}$ should be zero. Asdrubali, Sørensen, and Yosha (1996) show that the coefficient

(1994), Attanasio and Davis (1996), and Hayashi, Altonji, and Kotlikoff (1996); studies using macro-data include Obstfeld (1994b) and Lewis (1996). The International Real Business Cycles literature takes a somewhat different, although closely related, approach to testing for full risk sharing. See, e.g., Backus, Kehoe, and Kydland (1992), Stockman and Tesar (1995), and Canova and Ravn (1996). See Sørensen and Yosha (1998), Section 4.2, for a comparison of these approaches using OECD National Accounts data. Of related interest is a recent study by Forni and Reichlin (1999).

${ }^{11}$ They also study, in a unified framework, income insurance (via markets and the tax-transfer system) and consumption smoothing through saving and portfolio readjustment (e.g., borrowing and lending); see Mélitz and Zumer (1999) for a critical evaluation cum extension of their method, as well as for interesting empirical results. We return to the issue of consumption smoothing in Section 5.

${ }^{12}$ We disregard risk sharing across risk sharing groups. Since risk sharing between countries is limitedSørensen and Yosha (1998) - this is a reasonable assumption. 
$\beta_{1}$ measures the fraction of idiosyncratic GDP shocks that is not eliminated through crossregional insurance. More precisely, they show that in the regression

$$
\Delta \log \mathrm{GDP}_{i t}-\Delta \log \mathrm{PINC}_{i t}=\nu_{t}+\beta_{K} \Delta \log \mathrm{GDP}_{i t}+\epsilon_{i t},
$$

the coefficient $\beta_{K}$ measures the fraction of idiosyncratic shocks to GDP that is absorbed through cross-regional ownership of assets. $\left(\beta_{K}\right.$ equals $1-\beta_{1}$.) Thus, our measure of risk sharing through inter-regional capital markets is $\beta_{K}$. The intuition is that if there is no insurance, $\Delta \log \mathrm{GDP}_{i t}$ and $\Delta \log \mathrm{PINC}_{i t}$ comove perfectly and the left hand side of (1) does not comove with the regressor, $\Delta \log \mathrm{GDP}_{i t}$, making $\beta_{K}=0$. If there is perfect insurance, $\Delta \log \mathrm{PINC}_{i t}$ is unaffected by region-specific fluctuations in $\log \mathrm{GDP}_{i t}$, and (1) boils down to a regression of $\Delta \log \mathrm{GDP}_{i t}$ on itself, implying that $\beta_{K}=1$.

The following qualifications should be kept in mind: Since our measure of capital market smoothing, $\beta_{K}$, is based on personal income, it does not fully separate market-based income insurance through cross-border factor income from income smoothing through patterns of capital stock depreciation and, especially, adjustment of corporate saving. Typically, firms smooth dividend payments in response to economic performance. Using country level National Accounts data, Sørensen and Yosha (1998) show that corporate saving smoothes a significant portion of GDP shocks at the annual frequency, but not at the 3 -year frequency. ${ }^{13}$ Our regional data sets do not allow us to quantify the extent to which $\beta_{K}$ reflects cross-regional factor income flows versus adjustment of corporate saving rates. Further, our estimate of $\beta_{K}$ does not fully separate income smoothing via markets from income insurance provided by super-regional fiscal institutions. For example, in the United States, personal income includes social security transfers to individuals by the federal government. To correct for this, Asdrubali, Sørensen, and Yosha (1996) construct the variable "state income" that represents the income of a U.S. state prior to any federal tax or transfer. It is not possible to construct a similar variable for all the regions and countries which we study in the present article. $\beta_{K}$ is therefore an approximation to the measure of capital market smoothing in Asdrubali, Sørensen, and Yosha (1996). ${ }^{14}$

\footnotetext{
${ }^{13}$ See also Mélitz and Zumer (1999). For risk sharing groups that are groups of countries (e.g., the EC), we define "personal income" as the country's Net National Income (as defined in the OECD National Accounts) minus corporate saving. This definition gives the closest analogue to personal income (as defined for regions), that we can construct from the National Accounts data; see Sørensen and Yosha (1998).

${ }^{14}$ The measures of (capital market) risk sharing among communities of Spain, and among regions of Italy
} 
We turn to the measure of cross-regional insurance via super-regional taxes and transfers. Most tax-transfer systems were not designed to provide insurance (although there are exceptions, like unemployment or disability insurance funds), but progressivity of the tax code implies that taxes and transfers help smooth income. The following panel regression is designed to capture the amount of income smoothing provided by cross-regional taxes and transfers,

$$
\Delta \log \mathrm{PINC}_{i t}-\Delta \log \mathrm{PDINC}_{i t}=\nu_{t}+\beta_{T} \Delta \log \mathrm{GDP}_{i t}+\epsilon_{i t},
$$

where PDINC represents personal disposable income. The coefficient $\beta_{T}$ is positive if personal disposable income covaries less with GDP than personal income, i.e., if the "federal government" of the risk sharing group provides income insurance. It can be interpreted as the fraction of the cross-sectional variance (averaged over time) absorbed by the "federal" fiscal system of the risk sharing group; see Asdrubali, Sørensen, and Yosha (1996) for details. ${ }^{15}$ If overall income uncertainty is important, then it may be warranted to measure risk sharing as the combined fractions of idiosyncratic GDP shocks absorbed through cross-regional ownership of assets and via the super-regional tax-transfer system. Thus, we construct the measure $\beta_{K+T}$ obtained from the panel data regression

$$
\Delta \log \mathrm{GDP}_{i t}-\Delta \log \mathrm{PDINC}_{i t}=\nu_{t}+\beta_{K+T} \Delta \log \mathrm{GDP}_{i t}+\epsilon_{i t},
$$

where $\beta_{K+T}$ measures the total amount of income insurance, and conceptually, $\beta_{K+T}=\beta_{K}+$ $\beta_{T}$. Equation (3) is similar to equation (1), with personal disposable income substituted for personal income, and an analogous interpretation of the coefficient. For brevity we only display estimates of $\beta_{K+T}$ and not $\beta_{T}$.

In our empirical analysis, in this paper, we focus mainly on $\beta_{K}$, income insurance via markets, and to some extent on $\beta_{K}+\beta_{T}$, income insurance via markets and the fiscal system. We can compute, in an analogous manner, $\beta_{C}$, consumption smoothing via saving and dissaving, and $\beta_{K}+\beta_{T}+\beta_{C}$, total income and consumption smoothing. In Section 5 , we provide further details, but for the moment we focus on income insurance.

and the United Kingdom in Alberola and Asdrubali (1998) and Dedola, Usai, and Vannini (1998), respectively, are also calculated using simple personal income measures rather than the equivalent of "state income."

${ }^{15}$ In principle, one could regress $\Delta \log \mathrm{PDINC}_{i t}$ on $\Delta \log \mathrm{PINC}_{i t}$, and regard one minus the coefficient as a measure of risk sharing through the super-regional fiscal system. Such a measure might be more natural if one were to study smoothing of personal income, per se. In the present study, it is convenient to define all income and consumption smoothing relative to GDP shocks. 
It is worth noting that if a particular region in a risk sharing group, say a U.S. state, shares risk with regions in another group, say a region of the U.K., our risk sharing measures for both the U.S. and the U.K. will attribute this income smoothing to risk sharing within the U.S. and the U.K. Since measured risk sharing among countries is very small (see Sørensen, and Yosha (1998)), our measures of risk sharing can be safely regarded as genuinely measuring intra-group risk sharing.

\section{Measuring specialization}

We calculate specialization indices for the 2-digit International Standard Industrial Classification (ISIC) of manufacturing sectors. We do not use 1-digit sectors since the amount of specialization in, e.g., agriculture or mining, is determined mainly by endowments of fertile soil and extractable minerals. (We performed exploratory work at the 1-digit level, but obtained rather mixed results.) We were not able to collect consistent data at the 3-digit level for many regions and we suspect that risk sharing considerations may be less central in determining patterns of specialization at the 3-digit level (since many shocks may be common to several 3-digit industries; for instance, oil-shocks affecting most chemical industries). Each index is computed (for each region) for the relevant sample years and averaged over time. ${ }^{16}$

The indices are calculated as follows. Let $\operatorname{GDP}_{i}^{s}$ denote the GDP of sector $s$ in region $i$, and $\mathrm{GDP}_{i}^{M}$ the total manufacturing GDP of this region. We measure the specialization of a region by the distance between the vector of sector shares in region $i$ 's manufacturing GDP, $\operatorname{GDP}_{i}^{s} / \operatorname{GDP}_{i}^{M}$, and the vector of average sector shares across the regions other than $i$ in the risk sharing group,

$$
\operatorname{SPEC}_{1}^{i}=\sum_{s=1}^{S}\left(\frac{\mathrm{GDP}_{i}^{s}}{\operatorname{GDP}_{i}^{M}}-\frac{1}{J-1} \sum_{j \neq i} \frac{\operatorname{GDP}_{j}^{s}}{\operatorname{GDP}_{j}^{M}}\right)^{2},
$$

where $S$ is the number of sectors and $J$ is the number of regions in the group.

We find this variance-like measure natural given our focus on the effect of risk sharing on specialization. Notice that $\operatorname{SPEC}_{1}^{i}$, the "square deviations index," measures the extent to which region $i$ differs, in terms of the composition of manufacturing, from the other regions in $i$ 's risk sharing group, not from all the regions in the sample. Thus, the difference in the industrial composition of, for instance, Japan relative to other countries in the sample, does

\footnotetext{
${ }^{16}$ The alternative computation where we first average production over time and then calculate the index yields very similar results.
} 
not affect the specialization indices of individual Japanese prefectures. The difference in the industrial composition of, say, Japan and Canada does, however, affect the specialization indices of Japan and Canada when they are treated as regions within the OECD risk sharing group.

We also study the "absolute deviations index,"

$$
\operatorname{SPEC}_{2}^{i}=\sum_{s=1}^{S}\left|\frac{\mathrm{GDP}_{i}^{s}}{\mathrm{GDP}_{i}^{M}}-\frac{1}{J-1} \sum_{j \neq i} \frac{\mathrm{GDP}_{j}^{s}}{\operatorname{GDP}_{j}^{M}}\right|,
$$

which is a direct generalization of the index suggested by Krugman (1991) for pairs of countries. This measure attributes less weight to extreme values and is important for the purpose of verifying that the empirical results are robust to minor changes in specification. ${ }^{17}$

\section{Instrumental variables}

To deal with potential endogeneity of cross-regional holding of assets, we use instruments which facilitate risk sharing but are unlikely to be subject to reverse causality, such as shareholder rights (in particular, protection of minority shareholders from abuse by management or majority shareholders). The rationale for using such instruments is spelled out forcefully in La Porta et al. $(1997,1998)$. When the legal system provides protection for investors, they will be more inclined to buy securities issued by firms, directly or via intermediaries, to purchase real estate for investment purposes, or to keep large sums of money in long-term savings and insurance plans. Similarly, financial intermediaries will be more willing to lend and invest beyond the close circle of client firms. This is particularly true for cross-regional transactions that are truly at "arm's length." Thus, better investor protection via the nation-wide legal system entails more inter-regional income insurance via financial markets. La Porta et al. (1998) argue that shareholder rights vary systematically across countries, and consider four main legal traditions: Common Law, French-, German-, and Scandinavian tradition, with the most extensive shareholder rights in Common Law countries. The details need not concern us here- the point we want to make is that important determinants of financial de-

\footnotetext{
${ }^{17}$ Our specialization indices for a particular region are based on the distance between sector shares in the region and the average sector shares in other regions. An alternative is to use the distance to the weighted average (by population) of the sector shares in other regions, which is equivalent to comparing the sector shares in a region with the sector shares in the rest of the country. We found that such a modification has a very small effect on the empirical results.
} 
velopment, for instance the amount of shareholder protection, is determined by long-standing rules determined by political history. The upshot is that the legal tradition indicators are truly exogenous for risk sharing over our relatively short sample period (of about 20 years).

A highly capitalized (and hence liquid) stock market, and a developed financial sector contribute to nation-wide income smoothing. These variables are likely to be determined also by other factors besides legal investor protection (e.g., the educational and technological level in the country). We, therefore, also use the size of the financial sector relative to GDP as a separate instrument in order to gauge the sensitivity of our results to alternative (reasonable) instrumental variables.

\section{Empirical Analysis}

Table 1 displays descriptive statistics for our sample of regions and risk sharing groups. The number of regions varies considerably across groups. The United States and Japan consist of about 50 regions each, while in other risk sharing groups there are as few as 4 or 5 regions. There are substantial differences in the per capita GDP of the risk sharing groups. Latin American per capita GDP is very low, at $\$ 2237$, and the per capita GDP of Spain is less than half that of the wealthiest groups. Table 1 also shows that, on average, countries have a larger population than regions within countries, and that regions vary significantly in population. Larger regions are likely to be less specialized due to greater heterogeneity of the population or of geo-physical characteristics such as climate, landscape, and natural resources. Furthermore, in larger regions, scale economies in production may be exhausted for many industries. Finally, the table reveals that population density varies across regions, in particular within Japan. Population density may affect localization. Krugman (1991) argues that transportation costs determine where manufacturing industries locate, with high transportation cost industries locating in densely populated areas. Such patterns of localization may also cause industrial specialization to vary with population density.

To give an impression of the characteristics of highly specialized regions, we display in Table 2 some facts regarding the 15 most specialized regions. For comparison, Table 3 displays the same information for the 15 least specialized regions. The most specialized regions are

regions within countries, whereas 4 of the least specialized regions are countries. The share of manufacturing in regional gross product varies considerably across the highly specialized regions (from 4 percent in Hawaii and Wyoming to 35 percent in Pais Vasco). The least 
specialized regions show less variation in the share of manufacturing. On average, the more specialized regions have a smaller population, although some of the most specialized regions are larger than small OECD countries. Less specialized regions exhibit a somewhat higher population density than the most specialized regions (although Okinawa and Kanagawa in Japan are obvious exceptions). Based on these observations, our regressions control for size and population, and weight the regional data by manufacturing GDP.

In Figure 1, we display the distribution of the specialization indices across regions. The distribution of the squared deviations index, $\mathrm{SPEC}_{1}$, is clearly right-skewed while $\log \mathrm{SPEC}_{1}$ is almost "bell shaped." We, therefore, use the latter in the regressions in order to minimize the risk that our results are driven by outliers. The absolute deviations index, $\mathrm{SPEC}_{2}$, is much less skewed so we use this index without transformation in our regressions.

Table 4 displays income-based measures of risk sharing by risk sharing groups. We restrict attention, for the moment, to the first two columns, $\beta_{K}$ and $\beta_{K+T}$. According to both measures, Italy exhibits the highest amount of risk sharing between regions. The United States and Canada show a high a level of risk sharing through capital markets $\left(\beta_{K}\right)$ in comparison to the United Kingdom, Japan, and Spain. ${ }^{18}$ The ranking of the regions is the same according to both measures. The interpretation of $\beta_{K+T}$ for groups of countries is somewhat different since $\beta_{T}$ is calculated on the basis of international net transfers while for regions it uses cross-regional taxes and transfers to and from the central government of the country. Nevertheless, a clear result in Table 4 is that groups of countries, not surprisingly, exhibit the least amount of risk sharing for both income-based risk sharing measures.

Table 5 displays the average specialization indices of regions within each risk sharing group and a regression of the specialization index (the underlying year-by-year estimates) on a time trend.

The sample periods were chosen with two considerations in mind. First, we would like the samples used for calculating specialization to overlap with those used for calculating

\footnotetext{
${ }^{18}$ As mentioned in the previous section, our measures here do not isolate the effect of federal insurance to the same extent as the regressions in Asdrubali, Sørensen, and Yosha (1996), which were based on extensive calculations and imputations of the impact on income of the federal tax-transfer system (calculations that our data set does not allow us to replicate for many of the risk sharing groups). If we compare, for the United States in the 1980s (one of the periods for which Asdrubali, Sørensen, and Yosha (1996) provide results), the measure $\beta_{K}$ that we use here (which is based on personal income) to the measure in their paper, we find that $\beta_{K}$, as reported here, over-estimates income smoothing via markets by about 5 percent. Our main results are not likely to be affected by this discrepancy, although the results involving $\beta_{K}$ must be interpreted more broadly as also reflecting some risk sharing provided through the fiscal system of super-regional governments.
} 
risk sharing. Second, we would like a long sample for calculating risk sharing, because we (later) use the risk sharing index as a regressor. The longer the sample period, the smaller the standard errors of the risk sharing estimates and, consequently, the lower the errors-invariables bias. For countries with many regions and a reasonably long sample available for calculating both specialization and risk sharing, we chose the longest overlapping sample, as for the United States and the United Kingdom. For the OECD, for example, where we have a relatively small sample of countries, we chose a somewhat longer sample for calculating the index of risk sharing (in order to minimize measurement error) than that used for calculating the specialization indices, where we used the longest sample (of 2-digit manufacturing GDP data) available. Similarly, for Canada, where specialization can only be calculated for a rather short span of years, we calculated the risk sharing measure using a longer sample than that used for the specialization indices. We experimented with the sample lengths and fortunately, the results are not very sensitive to the exact sample periods chosen.

It is clear from Table 5 that regions within countries are much more specialized than countries within groups of countries such as the EC or Latin America. Regions of Spain are the most specialized and EC countries are the least specialized. These results hold for both specialization indices, although $\mathrm{SPEC}_{1}$ clearly varies more than $\mathrm{SPEC}_{2}$.

The regressions on a time trend reveal that specialization has been decreasing over time, albeit slowly. The coefficient is negative for both specialization indices, although it is not significant at the 5 percent level. (It is borderline significant for the squared deviations index, $\mathrm{SPEC}_{1}$.) We interpret this as reflecting a relation between specialization and economic development, but a study of this issue will divert us from the topic of the present paper. The result is consistent with Kim (1995) who finds that the specialization of U.S. states has declined markedly since the $1930 \mathrm{~s}$, a phenomenon that is consistent with a negative relation between income (or wealth) and specialization. The mechanism may be one, as described in Acemoglu and Zilibotti (1997), where a minimum scale in some technologies makes these unavailable to less developed countries. The time-series patterns in specialization are not likely to be important for the present study, where regressions of specialization indices on risk sharing measures are cross-sectional; but they underscore the potential importance of correcting for different levels of development, when risk sharing groups with disparate levels of per capita income are included.

Figure 2 displays a scatter plot of specialization (measured by the $\mathrm{SPEC}_{1}$ index) versus the market-based risk sharing index, $\beta_{K}$. Each point in the graph represents a region and 
the horizontal axis measures the amount of risk sharing, i.e., the amount of risk sharing in the group to which the region belongs. Since this number is identical for each region in a group, the data will form dots along a vertical line for each risk sharing group. The vertical axis measures the degree of specialization of the region. The positive relation between risk sharing and specialization in manufacturing is highlighted by the (univariate) regression line displayed.

Potentially, the positive slope fitted in Figure 2 may be spurious in the sense that it reflects left-out regressors such as population or population density. We, therefore, performed regressions of $\mathrm{SPEC}_{1}$ on $\beta_{K}$, controlling for the population size and density of each region, for the share of manufacturing in regional GDP, and for the average per capita GDP in each risk sharing group. In Figure 3, we show the relation between the specialization index, $\mathrm{SPEC}_{1}$, and the risk sharing measure, $\beta_{K}$, when the other regressors are controlled for. ${ }^{19}$ The positive slope is still clearly visible. (This is, however, only for illustration as our regression results below are based on a log-transformation of the specialization index.)

Table 6 displays regressions, for various samples of risk sharing groups, of $\log \mathrm{SPEC}_{1}$ on regional characteristics (population and population density), on the average per capita GDP of the risk sharing group, on this variable squared, and on the risk sharing measure $\beta_{K}$. The regressions are all weighted by the logarithm of (real) manufacturing GDP in each region. We also experimented with a dummy variable for regions for which the risk sharing group is (part of) a custom union (all groups except Latin America and non-EC OECD countries). This variable was not significant and is left out in the regressions we report. ${ }^{20}$

Sample A is our "preferred sample," leaving out Latin American countries for which the risk sharing measure is most likely to be imprecise (relying on extrapolations-see Appendixas well as bad data in the first place). Sample B leaves out risk sharing groups composed of countries. It is important to examine whether our results are entirely driven by the dichotomies "cross-country versus cross-regional risk sharing" or "cross-country versus crossregional capital and labor mobility," or by systematic differences in international and intrana-

\footnotetext{
${ }^{19}$ We regressed both the specialization index and the risk sharing measure on the other regressors and took the residuals. These residuals are plotted in Figure 3. By the Frisch-Waugh theorem, the slope of the displayed regression line corresponds to the coefficient $\beta_{K}$ that would be obtained in a multiple regression of the specialization index on the same regressors.

${ }^{20}$ We do not interpret this as implying that barriers to trade are not important for specialization in production, since our sample contains only two risk sharing groups for which trade barriers are likely to be important (and, furthermore, the Latin American data are not very reliable).
} 
tional trade patterns. For example, as previously mentioned, trade barriers may be important even if our sample is not able to document this. The results for sample B cannot, however, be driven by trade barriers or any other border effects since all the risk sharing groups in this sample are countries with fully integrated regions. Sample C leaves out Latin America, and Italy that exhibits a particularly large $\beta_{K}$. Sample D leaves out the United States (and Latin America) to see if the results are mainly driven by the 50 U.S. states. Sample E consists of all the regions including the Latin America group. Sample F leaves out Japan (and Latin America) for comparison to regressions using other risk sharing measures, which our data set does not allow us to calculate for Japan.

The results in Table 6 are qualitatively the same across the various samples, although there is variation in the magnitude and significance levels of some coefficients. In all samples, we find a negative sign on the per capita GDP of the risk sharing groups (GDP ${ }^{G}$ ) and a positive sign on this variable squared, both highly significant. ${ }^{21}$ For Sample E, which includes Latin America, the estimated coefficients of $\mathrm{GDP}^{G}$ and $\mathrm{GDP}^{G}$ squared are somewhat different compared to the other samples. This most likely indicates that patterns of specialization are somewhat different at lower levels of development, which is yet another reason (besides data issues) for leaving out Latin America in the other samples. Population density exhibits a clearly significant positive coefficient. It seems that the impact of population density on specialization is particularly strong in Japan, since the coefficient becomes insignificant when the Japanese prefectures are left out (see the last column in the table). This is not a focus of our paper, so we abstain from attempting to interpret this finding in more detail. Population shows a typically significant negative coefficient which is to be expected due to greater heterogeneity of large regions and large populations. Alternatively, this may reflect dis-economies of scale beyond a certain minimal level of output that is more likely reached in larger regions. (Clearly, large regions like California and Texas, not to speak of Germany and Japan in the samples including countries as "regions," cannot fully specialize in a narrow industry.) The share of manufacturing in GDP exhibits a positive coefficient, but is borderline significant.

We now turn to the coefficient of main interest: In sample A, the risk sharing measure,

\footnotetext{
${ }^{21}$ The point estimates of the coefficients imply that specialization is decreasing in GDF ${ }^{G}$ when GDF ${ }^{G}$ is low and increasing in $\mathrm{GDP}^{G}$ when it is high. This result is not quite robust to the functional form for GDP ${ }^{G}$, but we abstain from studying this issue in more detail as our purpose is simply to control for the level of income in our regressions of specialization on risk sharing.
} 
$\beta_{K}$, takes a coefficient of 1.21 , strongly significant with a t-value of $3.69 .^{22}$ This is our main result: Risk sharing matters for specialization. In the following we demonstrate that it is a robust finding. If we leave out risk sharing groups composed of countries (sample B) we have only six risk sharing groups, but the coefficient of the risk sharing measure is still clearly significant and the point estimate is 1.45 . The results for sample $B$, with no risk sharing groups composed of countries, cannot possibly be a consequence of trade barriers. Clearly, capital market integration plays a major role in determining patterns of industrial specialization.

The estimated coefficients of $\beta_{K}$ are similar for samples D and $E$ (without Italy and the United States, respectively). Including Latin America as a risk sharing group (sample E) again has little effect on the estimated coefficient, compared to sample A. Finally, the results for sample F (dropping Japan) also resemble those for sample A, except that the coefficient of $\beta_{K}$ is only borderline significant.

Our measure of risk sharing is an estimate and therefore subject to measurement error. ${ }^{23}$ Measurement error in a regressor is likely to lead to a biased estimate; it is, however, easy to demonstrate that the coefficient to a regressor measured with error (when there is only one coefficient with measurement error) is biased towards zero. Therefore, if we find a significant coefficient to the risk sharing measure (as we do) we can be confident that the coefficient, in the absence of measurement error, would be even larger. The robustness and similarity of the results across the various samples further strengthens our conviction that they are not seriously affected by measurement error. Overall, the clear impression from Table 6 is that more risk sharing is associated with greater specialization.

Table 7 examines robustness to specification, including choice of specialization index, while still relying on the risk sharing measure $\beta_{K}$. In some columns, the risk sharing measure is interacted with the share of manufacturing in each region's GDP: If manufacturing is only a tiny fraction of a particular region's GDP, then the production risk of the manufacturing sector can easily be diversified within the region. In such a case, the amount of cross-regional risk sharing may be of little importance for specialization patterns in manufacturing. The specification in Table 6 seemed more straight-forward to us, but the choice of functional

\footnotetext{
${ }^{22}$ To help interpret the magnitude of this coefficient, the range of the dependent variable, $\log \mathrm{SPEC}_{1}$, is from -6.29 to -1.49 so a coefficient of 1.21 is of substantial economic significance.

${ }^{23}$ The estimated standard errors in the regressions in Table 4 provide an order of magnitude of the measurement error of the risk sharing measure.
} 
form is not based on an explicit theoretical model and is, therefore, somewhat arbitrary. Fortunately, the results for the alternative specification are very similar to those reported in Table 6 in terms of statistical significance. In the third column of Table 7 we show results similar to those in the first column of Table 6, except that the data for each region are weighted by the logarithm of population. The results are very similar to the results found using manufacturing GDP weights. We further show regressions of the $\mathrm{SPEC}_{2}$ specialization index on the same regressors. The results are overall similar.

To further examine robustness, we split the samples used for calculating risk sharing and specialization roughly midway, obtaining an "early" and a "late" sample (since for Canada, specialization can only be calculated from 1987 on, we left it out in this exercise). Estimating risk sharing for the early and the late sample gave very similar results, except for a strong increase in $\beta_{K}$ for Spain, consistent with results in Alberola and Asdrubali (1998). We further found a small decrease in specialization for all risk sharing groups apart from the European Community, consistent with Kim's (1995) study of specialization in the United States. The point estimates in regressions for the early and late sub-periods, for both sample $\mathrm{A}$ and sample B, are similar to those reported in Table 6 and are significant for both samples. We do not report the detailed coefficients. ${ }^{24}$

We further estimated the model using risk sharing measures calculated with non-overlapping 3-year observations (3-year differencing of the data). Sørensen and Yosha (1998) found, using OECD country level data, that smoothing through corporate saving declines to near zero when moving from 1- to 3-year sampling. If failure to separate out the effect of adjustment in corporate saving rates affects the estimation of $\beta_{K}$, then we would expect to find quite different results using estimates of $\beta_{K}$ based on 1 - and 3 -year intervals. The results (not reported), however, are very close to those reported in Table 6 .

The consistency of the empirical results across the various samples and specifications demonstrates that, empirically, there is a robust positive relation between risk sharing and specialization, a relation which is at the heart of much theoretical work, but never documented in the data.

\footnotetext{
${ }^{24}$ The fact that the regressions of Table 6 yield very similar results for the sub-periods further convinces us that measurement error in the regressor $\beta_{K}$ has a minor effect on the results reported in Tables 6 and 7 .
} 


\section{Direction of causality: Instrumental variables estimation}

The potential for the extent of inter-regional risk sharing being determined by the amount of regional specialization calls for a careful interpretation of the above regressions. Fortunately, we have very good (in the sense of being exogenously determined) instrumental variables, as explained in the previous section. We use three different instruments: (1) protection of shareholder rights indices; (2) a cumulative protection of creditor rights index; and (3) the (average) GDP share of financial services, insurance, and real estate (FIRE). For shareholder rights, we use 4 variables from La Porta et al. (1998), Table 4. We select the instruments with the highest correlation with our risk sharing measure. (Using all instruments is not feasible since we have few risk sharing groups in our sample, and searching for the "best" set of instruments may invalidate the t-statistics (pre-testing bias)). We also use the overall index of creditor protection rights from La Porta et al. (1998), Table 2, column 5. In our sample, creditor protection rights are negatively correlated with shareholder protection rights (and with our risk sharing measure); so our interpretation is that creditor rights play the role of an alternative (inverse) measure of shareholder rights. Finally, we use the share of the financial sector in GDP obtained from $O E C D$ National Accounts. Since this instrument is from a different source than the creditor and shareholder protection indices, it serves as a further robustness check for the instrumental variables estimation.

The empirical results, displayed in Table 8, are very close to those reported in Table 6 , and display t-statistics for the coefficient of $\beta_{K}$ that are clearly significant at the 5 percent level (except for the second column in Table 8). The point estimates are always positive and in the same range as the estimates in Table $6 .^{25}$

The instrumental variables regressions provide strong evidence of a causal link running from risk sharing (income insurance) to specialization in production. We thus believe to have provided solid empirical evidence for an important mechanism through which a developed and reliable financial system, backed by a legal environment that protects investor rights, enhances specialization and - in light of the theoretical and empirical studies surveyed in the Introduction-promotes growth. ${ }^{26}$

\footnotetext{
${ }^{25}$ Formal Hausman-type tests for the regressions in Table 6 are never close to rejecting the null of exogeneity of $\beta_{K}$. These tests may have low power, so we attach more weight to the fact that the point estimates for the instrumental variables regressions take sensible values.

${ }^{26}$ The instrumental variables regressions are also consistent in the presence of measurement error in the risk sharing measure, so these results constitute yet more evidence that measurement error in this regressor dose
} 


\section{Further tests}

In Table 9, we display regressions using the measure of risk sharing based on disposable income, $\beta_{K+T}$, that captures the cumulative insurance role of capital markets and the fiscal system. These regressions use sample $\mathrm{F}$, as we do not have disposable income data for Japan. If the risk sharing provided by federal tax-transfer systems is important for specialization decisions, this measure should also be positively correlated with industrial specialization. The point estimates of the coefficients of $\beta_{K+T}$ are positive but not statistically significant. In light of the weak significance of the coefficient of $\beta_{K}$ in the last column of Table 6 (sample F), we cannot with confidence attribute the lack of statistical significance to the use of $\beta_{K+T}$ (rather than to the particular sample used, without the 47 Japanese prefectures). In order to determine with greater certainty which of the income-based risk sharing measures is best correlated with specialization, a much larger sample is needed; but the evidence in Table 9 , compared to Table 6 , raises the conjecture that capital market integration is more important for specialization than federal income insurance. It is nevertheless reassuring that the signs of the coefficients are not sensitive to the way the income-based risk sharing measure is defined.

We experimented with instrumental variables estimation for the risk sharing measure

$\beta_{K+T}$. For the "legal system" instruments, we do not get significant estimates, which is not surprising since the legal system is unlikely to be a determinant of government tax policy. When the share of FIRE in GDP is used as an instrument for $\beta_{K+T}$, we find results similar to those in Table 8.

\section{Consumption Based Measures of Risk Sharing}

In Section 2, we argued that regions will not specialize unless they have access to income insurance and, hence, consumption-based measures of risk sharing may be less than ideal for our purpose. We suggested that an income-based measure of risk sharing is most appropriate for our study. Nevertheless, since the proposition that risk sharing enhances specialization in production has been ubiquitously formulated within models where economic agents ultimately derive utility from consumption, we believe that an empirical investigation of the relation between a consumption-based measure of risk sharing and specialization is warranted.

To carry out such an analysis, we need a measure of the fraction of GDP shocks smoothed

not seriously affect our results. 
via saving and dis-saving. This measure is derived in the same fashion as the measure of smoothing through taxes and transfers. We regress the growth rate of personal disposable income minus the growth rate of consumption on the growth rate of GDP, controlling for aggregate GDP shocks by including time fixed effects:

$$
\Delta \log \mathrm{PDINC}_{i t}-\Delta \log \mathrm{CONS}_{i t}=\nu_{t}+\beta_{C} \Delta \log \mathrm{GDP}_{i t}+\epsilon_{i t} .
$$

The measure $\beta_{C}$ is positive if consumption covaries less with GDP than personal disposable income, measuring the fraction of region-specific shocks to GDP absorbed through adjustments in the saving rate. If regions consider income smoothing (through capital markets or the fiscal system) and consumption smoothing via saving behavior as close substitutes, then the risk sharing measure that is relevant for specialization decisions is the overall fraction of GDP shocks smoothed:

$$
\beta_{K+T+C}=\beta_{K}+\beta_{T}+\beta_{C} .
$$

We estimate $\beta_{K+T+C}$ directly from the (panel) regression $\Delta \log \mathrm{GDP}_{i t}-\Delta \log \mathrm{CONS}_{i t}=\nu_{t}+$ $\beta_{K+T+C} \Delta \log$ GDP $_{i t}+\epsilon_{i t}$. This allows us to obtain an estimate of $\beta_{K+T+C}$ also for Japan for which no measure of disposable personal income, consistent with our data, is available. (Due to the estimation procedure, the measure of overall smoothing is only approximately equal to the sum of the "partial" measures of smoothing.)

The estimated values of $\beta_{K+T+C}$ for the various risk sharing groups are displayed in the third column of Table $4 .{ }^{27}$ According to this measure, consumption is fully buffered against GDP shocks in Italy, but not elsewhere.

In Table 11, we display the relation between the consumption-based risk sharing measure, $\beta_{K+T+C}$, and specialization. The performance of this measure is clearly not good, with the sign of the coefficient to $\beta_{K+T+C}$ alternating between positive and negative, and the coefficient clearly insignificant. This is fully consistent with our analysis in Section 2: Specialization in production is mainly affected by the degree of capital market integration, and maybe by other income insurance mechanisms, but not by the amount of consumption smoothing through saving and dis-saving.

Another interpretation is simply that the determinants of consumption, and in particular

\footnotetext{
${ }^{27}$ For the United States, state level consumption is proxied by retail sales; see Asdrubali, Sørensen, and Yosha (1996) for details.
} 
consumption smoothing, are not well understood, and that measures of consumption need to be improved. Hence, we have many "consumption puzzles" (see the survey by Deaton (1992)), and Table 11 displays yet another. In any event, an important implication is that the exclusive focus of the empirical risk sharing literature on overall consumption smoothing, rather than on income smoothing - the first level of total consumption smoothing - may have been unwarranted.

\section{Concluding Remarks}

We provided evidence that risk sharing and industrial specialization are positively correlated using a large data set that combines international and intranational (inter-regional) observations. We demonstrated that this correlation is robust, surviving when variables whose omission can potentially generate a spurious correlation are controlled for. In particular, our evidence indicates that specialization patterns are not driven by higher barriers to international versus inter-regional trade or by higher factor mobility within versus across countries. We further demonstrated that the positive significant correlation between risk sharing and specialization is robust to most changes in the sample of regions and risk sharing groups. As instruments for the amount of inter-regional risk sharing we utilized quantitative measures of features of the legal system (for instance shareholder rights), which are likely to be exogenous to specialization in production but which facilitate risk sharing. We found strong evidence that the correlation between risk sharing and specialization indeed reflects a causal relation from risk sharing to specialization.

In the debate on European Monetary Unification, it has been argued-Frankel and Rose (1998) - that countries may experience more correlated shocks to GDP after entering a common currency area, due to the fact that a higher trade volume seems to be associated with more correlated GDP shocks. Our analysis adds a qualifier to this observation: If formation of a common currency area leads to more capital market integration and therefore also to more inter-country risk sharing, then countries will specialize more, which is likely to lead to less correlated GDP shocks. (Which effect is more important can only be determined from further empirical work.) $)^{28}$

\footnotetext{
${ }^{28}$ It is often assumed that it is easier for countries with more correlated output shocks to form a monetary union. In the presence of risk sharing contracts which smooth income, a more relevant criterion is the extent to which income shocks are correlated.
} 


\section{Appendix: Data}

1. OECD: We use data from OECD National Accounts Volume 2, Revision 1996, for population, national Consumer Price Indices (CPI), Gross Domestic Product (GDP), consumption, national income, national disposable income, and corporate saving for the years 1971-93; and for manufacturing GDP by type of activity (at current prices) for the years $1977-93$.

Manufacturing sub-levels are available by 2-digit ISIC sectors (see below) for 12 countries (Austria, Belgium, Canada, Denmark, Finland, France, Greece, Netherlands, New Zealand, Norway, United States, West Germany) for the period 1977-93. We use 7 of the 9 ISIC 2-digit manufacturing sectors, leaving out the very heterogeneous sector "Other." No data are available for "wood and wood products." 29 We use Net National Income minus corporate saving as the country level equivalent to personal income. The sample is 1971-93. Corporate saving is not available for all countries or years. To avoid using different countries in the calculation of specialization and risk sharing, we used only the countries for which we were able to calculate both indices. This issue is discussed below for the relevant subsets of the OECD sample. Exchange rate data are obtained from the IMF International Financial Statistics database. Land area is from the Statistical Abstract of the United States (1997).

2. United States: We use state level data from the Bureau of Economic Analysis (BEA). Data for manufacturing Gross State Product at current prices (GSP) at the industry level are available by state for the period 1977-94. (Washington D.C. is very atypical and is omitted.) We utilize BEA data for 21 manufacturing sub-sectors, which we aggregate to 9 ISIC 2-digit levels. Data for total GSP, personal income, personal disposable income, retail sales, and population by state are also from the BEA for the years 1977-94. Data are transformed to fixed prices using the United States national CPI. ${ }^{30}$ Land area is from the Statistical Abstract of the United States (1997).

\footnotetext{
${ }^{29}$ To get a sense of how serious this omission might be, we exploited the availability of these data for U.S. states, and calculated indices of specialization with and without the wood sector for all U.S. states. The results were not sensitive to the omission of the wood sector, so we believe that the non availability of wood sector data for the OECD countries is a minor issue.

${ }^{30}$ del Negro (1998) constructs price indices for individual states, but finds that risk sharing regressions are not substantially affected by using state specific price indices rather than the U.S.-wide price index.
} 
3. EC: Subset of OECD data. For the manufacturing levels, data are available for 6 countries (Belgium, Denmark, France, Greece, Netherlands, West Germany) for the period 1977-93. Greece is omitted since it is an outlier in the group in terms of income per capita. For Denmark 1971-80 and for the Netherlands 1971-76, corporate saving data are not available making it impossible to construct risk sharing measures that are comparable with the personal income-based measures that we use for regions within countries (see footnote 13). Thus, for Denmark and the Netherlands, these years are not used in the measurement of risk sharing, whereas for other countries the entire sample period (1971-93) is used.

4. non-EC OECD: We use data for Austria, Canada, Finland, and the United States. We are restricted to this limited sample since corporate saving data are not available for several countries (see the previous item).

5. Canada: Data for Canadian provinces are available from the CANSIM database maintained by Statistics Canada. We use manufacturing GDP at factor cost (at current prices) for each industry by province for the period 1987-93. The 3-digit data (21 sectors) are aggregated to the same 2-digit sectors as the United States BEA data. (At the 3 -digit level our data sources are not compatible.) The data are available for 5 provinces (Alberta, British Columbia, Manitoba, Ontario, Quebec) for 1987-93. Personal income, personal disposable income, consumption, population, and regional CPI are also available from CANSIM. The risk sharing measure is computed for the period 1979-95 for the same 5 provinces above. Data are transformed to real terms using each province's own yearly consumer price indices. Exchange rate data are obtained from the IMF International Financial Statistics database. Land area is also from CANSIM.

6. Japan: For the manufacturing sub-levels, we use employment data from the Statistical Yearbook for Japan, various issues, 1979-93. The data are available at the 3 -digit level (21 sectors) and aggregated to 2-digit sectors that are consistent with the data for the United States. Total GDP, personal income, consumption, prefectural CPI and population by prefecture are from the National Accounts-Japanese Prefectural Data published by Sinfonica. The risk sharing measure is computed for the period

Experimenting, we found that for other risk sharing groups, for instance Canada, our results change little if national CPI, rather than regional CPIs, are used. 
1975-93. Manufacturing total GDP for Japanese prefectures is from Annual Report on Prefectural Accounts, 1997, published by the Economic Planning Agency of Japan. It covers all prefectures in various years. We have data for all prefectures for $1975,80,85,90,91,92,93$. Current price data are deflated using the prefectural consumer price index. Exchange rate data are obtained from the IMF International Financial Statistics database. Land area is from the Statistical Yearbook.

7. Latin America: For manufacturing sectors of Latin American countries we use gross value added (at current prices), in INDSTAT3, Industrial Statistics Database, 3-Digit level of ISIC Code (1998), from UNIDO, United Nations Industrial Development Organization. This data base contains time series for the years 1963-96, according to availability, for 175 countries. The data are arranged according to ISIC 3 -digit categories, which provides for the inclusion of 28 industries in the manufacturing sector. We aggregated the data to 2-digit levels consistent with the U.S. data. The data are available for 9 countries (Argentina, Bolivia, Chile, Colombia, Costa Rica, Ecuador, Peru, Venezuela, Uruguay) for the period 1979-90. Total GDP and population are obtained from Arreaza (1998). The risk sharing estimates, reported in Arreaza (1998), are calculated using 18 countries - those mentioned above plus Brazil, El Salvador, Guatemala, Honduras, Mexico, Nicaragua, Panama, Paraguay, and Dominican Republic. Data for Net National Income or corporate saving are not available and Arreaza (1998) calculated the amount of risk sharing obtained via international factor income flows. We have extrapolated this measure to be comparable with our risk sharing measure for the OECD countries. ${ }^{31}$ Exchange rate data are obtained from the IMF International Financial Statistics database. Land area is from Statistical Abstract of the United States (1997).

8. Italy: For regional manufacturing 2-digit sectors, we use gross value added at factor cost (at current prices) from Eurostat's regional database REGIO. This data set covers economic accounts for all regions of Europe for (subsets of) the period 1960-95. Unfortunately, there are no data for the wood sector. Total manufacturing GDP, population,

\footnotetext{
${ }^{31}$ For the OECD countries we can calculate the amount of risk sharing $\left(\beta_{K}\right)$ as described in the text, and we can also calculate the amount of risk sharing obtained via international factor income flows. We then (for the OECD countries) calculate the ratio of $\beta_{K}$ to the factor income flow-based measure. For Latin America, we then multiply Arreaza's factor income flow-based measure with this ratio, arriving at an approximate $\beta_{K}$-value for Latin America.
} 
and land area are also from this source. The data are available for all Italian regions for the years 1975-94. The risk sharing measure is calculated for the period 1983-92 using all regions. The data are from "Conti economici regionali delle amministrazioni publiche e delle famiglie," Italian National Institute of Statistics-Istituto Nazionale di Statistica (ISTAT). ${ }^{32}$ We used total GDP, personal disposable income, consumption, population and total CPI. Personal income is calculated as personal disposable income plus taxes. The indices are also calculated for 1983-92 to be compatible with the risk sharing measure. ECU exchange rate data are from the IMF International Financial Statistics database.

9. Spain: For the manufacturing sectors of communities of Spain, we use gross value added at factor cost (at current prices) at the 2-digit level, from Eurostat's regional database REGIO. Again, wood sector data are not available. Total manufacturing GDP, population, and land area are also from this source. Data are available for 16 communities of Spain (out of 18) for the period 1980-92. We do not have data for the Baleares and Ceuta y Melilla. The risk sharing measure is calculated for the period 1981-91 using the same 16 communities. Data for regional GDP, personal income, personal disposable income, consumption, population, and CPI are available bi-annually from the Spanish National Institute of Statistics- Instituto Nacional de Estadistica (INE)-Regional Accounts of Spain, various issues.

10. United Kingdom: For the manufacturing sectors of regions of the United Kingdom we use gross value added at factor cost (at current prices) and at the 2-digit level, from Eurostat's regional database REGIO. The data for the wood, non-metallic mineral products, and the basic metal industries sectors are not available. Total manufacturing GDP, population, and land area are also from this source. Data are available for all U.K. regions for the period 1978-93. The risk sharing measure is calculated for the period 1978-93 using all U.K. regions. The data are from the Regional Trends 1965-95 CD-ROM from the Office of National Statistics. We use total GDP, personal income, personal disposable income, consumption, population, and total CPI.

\footnotetext{
${ }^{32}$ The data were kindly provided by Jacques Mélitz and Frédéric Zumer to whom we are very grateful; see Mélitz and Zumer (1999).
} 
The 2-digit ISIC manufacturing level codes (Revision 2) are:

\begin{tabular}{ll}
\hline \hline ISIC Code & Category \\
& \\
31 & Food, beverages and tobacco \\
32 & Textile, wearing apparel and leather industries \\
33 & Wood and wood products including furniture \\
34 & Paper and paper products, printing and publishing \\
35 & Chemicals and chemical petroleum, coal, rubber and plastic products \\
36 & Non-metallic mineral products, except products of petroleum and coal \\
37 & Basic metal industries \\
38 & Fabricated metal products, machinery and equipment \\
39 & Other manufactured products* \\
\hline \hline
\end{tabular}

* Not included in our sample 


\section{References}

Acemoglu, Daron and Fabrizio Zilibotti (1997), "Was Prometheus Unbound by Chance? Risk, Diversification, and Growth," Journal of Political Economy 105, 709-751.

Alberola, Enrique and Pierfederico Asdrubali (1998), "How do Countries Smooth Regional Disturbances? Risk Sharing in Spain: 1973-1993," mimeo., Bank of Spain.

Altug, Sumru, and Robert A. Miller (1990), "Household Choices in Equilibrium," Econometrica $58,543-570$.

Anderson, James E. (1981), "The Heckscher-Ohlin and Travis-Vanek Theorems under Uncertainty," Journal of International Economics 11, 239-247.

Arreaza, Adriana (1998), "Consumption Smoothing, Capital Flows, and Fiscal Policy in Latin American Countries," mimeo., Brown University.

Asdrubali, Pierfederico, Bent E. Sørensen, and Oved Yosha (1996), "Channels of Interstate Risk Sharing: United States 1963-90," Quarterly Journal of Economics 111, 10811110 .

Athanasoulis, Stefano and Eric van Wincoop (1998), "Risk Sharing within the United States: What Have Financial Markets and Fiscal Federalism Accomplished?" Federal Reserve Bank of New York, Research Paper no. 9808.

Attanasio, Orazio, and Steve Davis (1996), "Relative Wage Movements and the Distribution of Consumption," Journal of Political Economy 104, 1227-1262.

Backus, David, Patrick Kehoe, and Finn Kydland (1992), "International Real Business Cycles," Journal of Political Economy 100, 745-775.

Brainard, William C. and Richard N. Cooper (1968), "Uncertainty and Diversification of International Trade," Food Research Institute Studies in Agricultural Economics, Trade, and Development, 8, 257-285.

Campbell, John Y., and Angus Deaton, (1989), "Why is Consumption so Smooth?" Review of Economic Studies 56, 357-373.

Canova, Fabio, and Morten Ravn, 1996, "International Consumption Risk Sharing," International Economic Review 37, 573-601.

Cochrane, John (1991), “A Simple Test of Consumption Insurance," Journal of Political Economy 99, 957-976.

Crucini, Mario J. (1999), “On International and National Dimensions of Risk Sharing," Review of Economics and Statistics 81, 73-84. 
Deaton, Angus (1992), Understanding Consumption, New York: Oxford University Press.

Dedola, Luca, Stefano Usai, and Marco Vannini (1998), "An Assessment of Regional Risk Sharing in Italy and the United Kingdom," forthcoming in: John Adams and Francesco Pigliaru, eds., Economic Growth and Change: National and Regional Patterns (Elgar, Cheltenham).

del Negro, Marco (1998), "Aggregate Risk Sharing Across US States and Across European Countries," Working Paper, Yale University.

Feeney, JoAnne (1994), "Goods and Asset Market Interdependence in a Risky World," International Economic Review 35, 551-564.

Feeney, JoAnne (1997), "International Risk Sharing, Learning by Doing, and Growth," mimeo.

Forni, Mario, and Lucrezia Reichlin (1999), "Risk and Potential Insurance in Europe," European Economic Review, forthcoming.

Frankel, Jeffrey, and Andrew Rose (1998), "The Endogeneity of the Optimum Currency Area Criterion," Economic Journal 108, 1009-1025.

French, K. and J. Poterba (1991), "Investor Diversification and International Equity Markets," American Economic Review: Papers and Proceedings 81, 222-226.

Greenwood, Jeremy and Boyan Jovanovic (1990), "Financial Development, Growth, and the Distribution of Income," Journal of Political Economy 98, 1076-1107.

Grossman, Gene and Assaf Razin (1984), "The Pattern of Trade in a Ricardian Model with Country-Specific Uncertainty," International Economic Review 26, 193-202.

Grossman, Gene and Assaf Razin (1985), "International Capital Movements Under Uncertainty," Journal of Political Economy 92, 286-306.

Hayashi, Fumio, Joseph Altonji, and Laurence Kotlikoff (1996), "Risk Sharing Between and Within Families," Econometrica 64, 261-294.

Helpman, Elhanan (1981), "International Trade in the Presence of Product Differentiation, Economies of Scale and Monopolistic Competition: A Chamberlin-Heckscher-Ohlin Approach," Journal of International Economics 11, 305-340.

Helpman, Elhanan (1984), "Increasing Returns, Imperfect Markets, and Trade Theory," in: Ronald W. Jones and Peter Kenen, eds., Handbook of International Economics, Volume 1, New York: Elsevier Science

Helpman, Elhanan (1988), "Trade Patterns under Uncertainty with Country Specific Shocks," Econometrica 56, 645-659. 
Helpman, Elhanan and Assaf Razin (1978a), "Uncertainty and International Trade in the Presence of Stock Markets," Review of Economic Studies 45, 239-250.

Helpman, Elhanan and Assaf Razin (1978b), A Theory of International Trade under Uncertainty, New York: Academic Press.

Hess, Gregory D. and Kwanho Shin (1998), "Risk Sharing by Households Within and Across Regions and Industries," Working Paper, University of Kansas.

Hufbauer, Gary C. and John G. Chilas (1974), "Specialization by Industrial Countries," in: Herbert Giersch, ed., The International Division of Labour: Problems and Perspectives (J.C.B. Mohr, Tübingen).

Kemp, Murray C. and Nissan Liviatan (1973), "Production and Trade Patterns under Uncertainty," The Economic Record 49, 215-227.

Kim, Sukkoo (1995), "Expansion of Markets and the Geographic Distribution of Economic Activities: the Trends in US Regional Manufacturing Structure 1860-1987," Quarterly Journal of Economics 110, 881-908.

King, Robert and Ross Levine (1993), "Finance and Growth: Schumpeter Might be Right," Quarterly Journal of Economics 108, 717-737.

Krugman, Paul (1979), "Increasing Returns, Monopolistic Competition, and International Trade," Journal of International Economics 9, 469-479.

Krugman, Paul (1991), Geography and Trade, Cambridge, MA: MIT Press.

La Porta, Rafael, Florencio Lopez-de-Silanes, Andrei Shleifer, and Robert Vishny (1997), "Legal Determinants of External Finance," Journal of Finance 52, 1131-1150.

La Porta, Rafael, Florencio Lopez-de-Silanes, Andrei Shleifer, and Robert Vishny (1998), "Law and Finance," Journal of Political Economy 106, 1113-1155.

Lewis, Karen (1996), "What Can Explain the Apparent Lack of International Consumption Risk Sharing?," Journal of Political Economy 104, 267-297.

Levine, Ross, and Sara Zervos (1998), "Stock Markets, Banks, and Economic Growth," American Economic Review 88, 537-558.

Mace, Barbara J. (1991), "Full Insurance in the Presence of Aggregate Uncertainty," Journal of Political Economy 99, 928-956.

Mélitz, Jacques, and Frédéric Zumer (1999), "Interregional and International Risk Sharing and Lessons for EMU," Carnegie-Rochester Conference Series on Public Policy, forthcoming. 
Obstfeld, Maurice (1994a), "Risk-Taking, Global Diversification, and Growth," American Economic Review 84, 1310-1329.

Obstfeld, Maurice (1994b), “Are Industrial-Country Consumption Risks Globally Diversified?," in: Leonardo Leiderman and Assaf Razin, eds., Capital Mobility: The Impact on Consumption, Investment, and Growth (Cambridge University Press, New York).

Rajan, Raghuram, and Luigi Zingales (1998), "Financial Dependence and Growth," American Economic Review 88, 559-586.

Ravallion, Martin and Shubham Chaudhuri (1997), "Risk and Insurance in Village India: Comment," Econometrica 65, 171-184.

Ruffin, Roy (1974), “Comparative Advantage Under Uncertainty," Journal of International Economics 4, 261-273.

Saint-Paul, Gilles (1992), "Technological Choice, Financial Markets and Economic Development," European Economic Review 36, 763-781.

Sørensen, Bent E. and Oved Yosha (1998), "International Risk Sharing and European Monetary Unification," Journal of International Economics 45, 211-238.

Stockman, Alan, and Linda Tesar (1995), "Tastes and Technology in a Two-Country Model of the Business Cycle: Explaining International Comovements," American Economic Review 85, 168-185.

Tesar, Linda, and Ingrid Werner (1995), “Home Bias and High Turnover," Journal of International Money and Finance 14, 467-492.

Townsend, Robert, 1994, "Risk and Insurance in Village India," Econometrica 62, 539-591.

Zingales, Luigi (1995), "What Determines the Value of Corporate Votes?," Quarterly Journal of Economics 110, 1047-1073. 
Table 1: Descriptive Statistics

\begin{tabular}{|c|c|c|c|c|c|c|c|c|}
\hline \multirow[t]{2}{*}{$\begin{array}{l}\text { Risk Sharing } \\
\text { Group }\end{array}$} & \multirow{2}{*}{$\begin{array}{r}\text { Number } \\
\text { of } \\
\text { Regions }\end{array}$} & \multirow{2}{*}{$\begin{array}{l}\text { GDP Per } \\
\text { Capita of Risk } \\
\text { Sharing Group }\end{array}$} & \multicolumn{3}{|c|}{$\begin{array}{l}\text { Population } \\
\text { of the Regions }\end{array}$} & \multicolumn{3}{|c|}{$\begin{array}{l}\text { Population density } \\
\text { of the Regions }\end{array}$} \\
\hline & & & avg & $\max$ & $\min$ & avg & $\max$ & $\min$ \\
\hline Italy & 20 & 11435 & 2854 & 8877 & 114 & 450 & 1066 & 89 \\
\hline United States & 50 & 16075 & 4777 & 26972 & 472 & 161 & 1023 & 1 \\
\hline Canada & 5 & 15341 & 4854 & 10284 & 1110 & 13 & 29 & 5 \\
\hline United Kingdom & 11 & 10489 & 5171 & 17257 & 1576 & 780 & 2240 & 170 \\
\hline Japan & 47 & 16125 & 2577 & 11792 & 613 & 1613 & 15143 & 173 \\
\hline Spain & 16 & 6854 & 2355 & 6716 & 258 & 338 & 1544 & 54 \\
\hline EC countries & 5 & 12824 & 32700 & 78609 & 5128 & 623 & 1199 & 262 \\
\hline non-EC countries & 4 & 15369 & 69342 & 238705 & 4892 & 88 & 239 & 7 \\
\hline L.A. countries & 9 & 2237 & 13945 & 29719 & 2505 & 55 & 128 & 14 \\
\hline
\end{tabular}

Notes: GDP: U.S. dollars. Population: thousand persons. Population density: persons/square miles. Italy: all provinces. United States: all states excluding DC. Canada: Quebec, Ontario, Manitoba, Alberta, British Columbia. United Kingdom: all regions. Japan: all prefectures. Spain: 16 communities out of 18. EC countries: Belgium, Denmark, France, Germany, Netherlands. Non-EC countries: Austria, Canada, Finland, United States. Latin American countries: Argentina, Bolivia, Chile, Colombia, Costa Rica, Ecuador, Peru, Venezuela, Uruguay. 
Table 2: Some Facts about the 15 Most Specialized Regions

\begin{tabular}{|c|c|c|c|c|c|}
\hline Regions & $\begin{array}{r}\text { Sector Constituting } \\
\text { Highest Share } \\
\text { in Manufacturing }\end{array}$ & $\begin{array}{r}\text { Region's } \\
\text { GDP } \\
\text { Per Capita }\end{array}$ & $\begin{array}{r}\text { Share of } \\
\text { Manufacturing in } \\
\text { Region's GDP }\end{array}$ & $\begin{array}{r}\text { Region's } \\
\text { Population }\end{array}$ & $\begin{array}{r}\text { Region's } \\
\text { Population } \\
\text { Density }\end{array}$ \\
\hline Montana (US) & 33 & 13257 & 0.08 & 808 & 6 \\
\hline Alaska (US) & 31 & 36409 & 0.04 & 505 & 1 \\
\hline Delaware (US) & 35 & 20171 & 0.28 & 635 & 325 \\
\hline Asturias (SP) & 37 & 6142 & 0.22 & 113 & 274 \\
\hline Hawaii (US) & 31 & 19113 & 0.04 & 1048 & 163 \\
\hline Louisiana (US) & 35 & 19893 & 0.15 & 4273 & 98 \\
\hline Valle D'aosta (IT) & 37 & 12153 & 0.17 & 114 & 89 \\
\hline Wyoming (US) & 35 & 23517 & 0.04 & 472 & 5 \\
\hline Canarias (SP) & 31 & 5905 & 0.07 & 1440 & 510 \\
\hline West Virginia (US) & 35 & 11869 & 0.18 & 1878 & 78 \\
\hline Okinawa (JA) & 31 & 11043 & 0.07 & 1185 & 1342 \\
\hline Kanagawa (JA) & 38 & 16438 & 0.34 & 7567 & 8042 \\
\hline Hokkaido (JA) & 31 & 14250 & 0.12 & 5647 & 174 \\
\hline Extremadura (SP) & 31 & 4063 & 0.07 & 1098 & 68 \\
\hline Pais Vasco (SP) & 38 & 7557 & 0.35 & 2143 & 757 \\
\hline
\end{tabular}

Notes: GDP: U.S. dollars. Population: thousand persons. Population density: persons/square miles. 31: Food, beverages and tobacco. 33: Wood and wood products including furniture. 35: Chemicals and chemical petroleum, coal, rubber and plastic products. 37: Basic metal industries. 38: Fabricated metal products, machinery and equipment. IT: Italy, US: United States, SP: Spain, JA: Japan. 
Table 3: Some Facts about the 15 Least Specialized Regions

\begin{tabular}{|c|c|c|c|c|}
\hline & $\begin{array}{r}\text { Region's } \\
\text { GDP } \\
\text { Per Capita }\end{array}$ & $\begin{array}{r}\text { Share of } \\
\text { Manufacturing in } \\
\text { Region's GDP }\end{array}$ & $\begin{array}{l}\text { Region's } \\
\text { Population }\end{array}$ & $\begin{array}{r}\text { Region's } \\
\text { Population } \\
\text { Density }\end{array}$ \\
\hline Canada (NEC) & 13651 & 0.15 & 26137 & 7 \\
\hline France (EC) & 13466 & 0.21 & 55323 & 262 \\
\hline Niigata (JA) & 14035 & 0.25 & 2470 & 579 \\
\hline Kumamoto (JA) & 12497 & 0.17 & 1829 & 679 \\
\hline Quebec (CA) & 13488 & 0.16 & 7016 & 13 \\
\hline Y.H. (UK) & 7983 & 0.22 & 4931 & 821 \\
\hline Scotland (UK) & 8283 & 0.20 & 5131 & 171 \\
\hline Iwate (JA) & 11863 & 0.20 & 1422 & 246 \\
\hline Abruzzo (IT) & 9335 & 0.18 & 1249 & 296 \\
\hline Belgium (EC) & 12641 & 0.20 & 9900 & 848 \\
\hline Tennessee (US) & 13935 & 0.26 & 4759 & 115 \\
\hline Galicia (SP) & 4915 & 0.17 & 2816 & 245 \\
\hline Yamagata (JA) & 12519 & 0.24 & 1256 & 436 \\
\hline Colombia (LA) & 1152 & 0.19 & 28124 & 70 \\
\hline Arkansas (US) & 11953 & 0.25 & 2328 & 44 \\
\hline
\end{tabular}

Notes: GDP: U.S. dollars. Population: thousand persons. Population density: persons/square miles. NEC: non-EC, JA: Japan, CA: Canada, Y.H.: Yorkshire and Humberside, UK: United Kingdom, IT: Italy, SP: Spain, LA: Latin America. 
Table 4: Risk Sharing-

Regions within Countries versus Groups of Countries

\begin{tabular}{|c|c|c|c|c|}
\hline $\begin{array}{l}\text { Risk } \\
\text { Sharing } \\
\text { Group }\end{array}$ & Sample & $\begin{array}{c}\text { Risk } \\
\text { Sharing } \\
\beta_{K} \\
\end{array}$ & $\begin{array}{c}\text { Risk } \\
\text { Sharing } \\
\beta_{K+T}\end{array}$ & $\begin{array}{c}\text { Risk } \\
\text { Sharing } \\
\beta_{K+T+C}\end{array}$ \\
\hline Italy & $1983-92$ & $\begin{array}{c}79.9 \\
(3.7)\end{array}$ & $\begin{array}{c}81 \\
(4.2)\end{array}$ & $\begin{array}{c}100 \\
(2.3)\end{array}$ \\
\hline United States & $1977-94$ & $\begin{array}{l}59.2 \\
(1.5)\end{array}$ & $\begin{array}{l}64.8 \\
(1.6)\end{array}$ & $\begin{array}{r}67.5 \\
(4.6)\end{array}$ \\
\hline Canada & $1979-95$ & $\begin{array}{c}55.9 \\
(5.6)\end{array}$ & $\begin{array}{l}62.4 \\
(6.9)\end{array}$ & $\begin{array}{l}71.1 \\
(3.9)\end{array}$ \\
\hline United Kingdom & $1978-93$ & $\begin{array}{l}37.8 \\
(5.8)\end{array}$ & $\begin{array}{c}35.1 \\
(7.6)\end{array}$ & $\begin{array}{c}84.6 \\
(9)\end{array}$ \\
\hline Japan & $1975-93$ & $\begin{array}{l}22.7 \\
(2.1)\end{array}$ & $\mathrm{NA}$ & $\begin{array}{c}92.1 \\
(2.2)\end{array}$ \\
\hline Spain & $1981-91$ & $\begin{array}{l}19.2 \\
(5.4)\end{array}$ & $\begin{array}{l}33.5 \\
(7.9)\end{array}$ & $\begin{array}{l}89.8 \\
(8.2)\end{array}$ \\
\hline \multicolumn{2}{|c|}{ Average for regions within countries } & 45.8 & 55.4 & 84.2 \\
\hline EC countries & $1971-93$ & $\begin{array}{c}11 \\
(5.1)\end{array}$ & $\begin{array}{c}14.1 \\
(1.6)\end{array}$ & $\begin{array}{l}43.3 \\
(5.9)\end{array}$ \\
\hline non-EC countries & $1971-93$ & $\begin{array}{l}13.1 \\
(5.7)\end{array}$ & $\begin{array}{c}13 \\
(5.9)\end{array}$ & $\begin{array}{l}44.2 \\
(4.2)\end{array}$ \\
\hline L.A. countries & $1973-93$ & 11 & 14.1 & 43.3 \\
\hline \multicolumn{2}{|c|}{ Average for groups of countries } & 12.6 & 13.7 & 43.6 \\
\hline
\end{tabular}

Notes: Standard errors in parentheses. Risk sharing groups: see notes to Table 1. NA: Not applicable. 
Table 5: Specialization-

Regions within Countries versus Groups of Countries

\begin{tabular}{lrcc}
\hline \hline $\begin{array}{l}\text { Risk } \\
\text { Sharing } \\
\text { Group }\end{array}$ & Sample & $\begin{array}{c}\text { Specialization } \\
\text { Index } \\
\left(\mathrm{SPEC}_{1} * 10\right)\end{array}$ & $\begin{array}{c}\text { Specialization } \\
\text { Index } \\
\left(\mathrm{SPEC}_{2}\right)\end{array}$ \\
\hline Italy & $1983-92$ & 0.46 & 0.40 \\
United States & $1977-94$ & 0.63 & 0.46 \\
Canada & $1987-93$ & 0.43 & 0.40 \\
United Kingdom & $1978-93$ & 0.32 & 0.30 \\
Japan & $1979-93$ & 0.42 & 0.43 \\
Spain & $1980-92$ & 0.73 & 0.52 \\
Average for regions within countries & 0.50 & 0.42 \\
\hline EC countries & $1977-93$ & 0.13 & 0.23 \\
non-EC countries & $1977-93$ & 0.21 & 0.27 \\
L.A. countries & $1977-90$ & 0.34 & 0.35 \\
Average for groups of countries & 0.23 & 0.28 \\
\hline & & & \\
Coefficient on time trend ${ }^{*} 1000$ & $(1.91)$ & $(1.32)$ \\
& & \\
\hline \hline
\end{tabular}

Notes: The specialization indices are defined in Section 3. Risk sharing groups: see notes to Table 1. The last 2 lines reports the coefficient, $\psi$ and the respective t-ratio in the following fixed effects regression where time denotes a time trend: $\operatorname{SPEC}_{i t}=\alpha_{i}+\psi$ time $_{t}+\epsilon_{i t}$ 
Table 6: Regression Results I

Dependent variable-Specialization index $\log \operatorname{SPEC}_{1}^{i}$

\begin{tabular}{|c|c|c|c|c|c|c|}
\hline Sample & $\mathrm{A}$ & B & $\mathrm{C}$ & $\mathrm{D}$ & $\mathrm{E}$ & $\mathrm{F}$ \\
\hline Observations & 158 & 149 & 138 & 108 & 167 & 111 \\
\hline $\mathrm{GDP}^{G}$ & $\begin{array}{l}-0.90 \\
(3.43)\end{array}$ & $\begin{array}{l}-1.00 \\
(3.19)\end{array}$ & $\begin{array}{l}-0.90 \\
(2.86)\end{array}$ & $\begin{array}{l}-1.10 \\
(3.24)\end{array}$ & $\begin{array}{l}-0.30 \\
(2.80)\end{array}$ & $\begin{array}{l}-0.90 \\
(3.07)\end{array}$ \\
\hline$\left(\mathrm{GDP}^{G}\right)^{2}$ & $\begin{array}{c}0.04 \\
(3.44)\end{array}$ & $\begin{array}{c}0.04 \\
(3.17)\end{array}$ & $\begin{array}{c}0.04 \\
(2.78)\end{array}$ & $\begin{array}{c}0.04 \\
(3.15)\end{array}$ & $\begin{array}{c}0.01 \\
(2.64)\end{array}$ & $\begin{array}{c}0.04 \\
(3.17)\end{array}$ \\
\hline Population Density & $\begin{array}{c}0.81 \\
(2.81)\end{array}$ & $\begin{array}{c}0.98 \\
(3.28)\end{array}$ & $\begin{array}{c}0.82 \\
(2.67)\end{array}$ & $\begin{array}{c}0.73 \\
(2.39)\end{array}$ & $\begin{array}{c}0.84 \\
(2.90)\end{array}$ & $\begin{array}{c}2.56 \\
(1.07)\end{array}$ \\
\hline $\log$ Population & $\begin{array}{l}-0.11 \\
(1.87)\end{array}$ & $\begin{array}{l}-0.22 \\
(2.66)\end{array}$ & $\begin{array}{l}-0.11 \\
(1.62)\end{array}$ & $\begin{array}{l}-0.03 \\
(0.41)\end{array}$ & $\begin{array}{l}-0.16 \\
(2.95)\end{array}$ & $\begin{array}{l}-0.17 \\
(2.02)\end{array}$ \\
\hline Manufacturing GDP Share & $\begin{array}{c}1.54 \\
(1.73)\end{array}$ & $\begin{array}{c}1.27 \\
(1.47)\end{array}$ & $\begin{array}{c}1.39 \\
(1.39)\end{array}$ & $\begin{array}{c}1.84 \\
(1.74)\end{array}$ & $\begin{array}{c}1.68 \\
(1.90)\end{array}$ & $\begin{array}{c}2.26 \\
(1.76)\end{array}$ \\
\hline$\beta_{K}$ & $\begin{array}{c}1.21 \\
(3.69)\end{array}$ & $\begin{array}{c}1.45 \\
(3.22)\end{array}$ & $\begin{array}{c}1.21 \\
(2.76)\end{array}$ & $\begin{array}{c}1.51 \\
(2.88)\end{array}$ & $\begin{array}{c}1.08 \\
(3.33)\end{array}$ & $\begin{array}{c}0.90 \\
(1.87)\end{array}$ \\
\hline $\bar{R}^{2}$ & 0.73 & 0.68 & 0.71 & 0.74 & 0.72 & 0.77 \\
\hline
\end{tabular}

Notes: GDP ${ }^{G}$ : Gross domestic product per capita of risk sharing group G.

"Manufacturing GDP Share" is the average (over the sample) of the share of manufacturing GDP in total GDP of each region.

All variables in all regressions are weighted by log of manufacturing GDP.

Sample A: Full sample minus Latin America.

Sample B: No Countries (full sample minus OECD and Latin America).

Sample C: Full sample minus Latin America and Italy.

Sample D: Full sample minus Latin America and the United States.

Sample E: Full sample.

Sample F: Full sample minus Latin America and Japan.

t-values in parentheses. 
Table 7: Regression Results II

Robustness-Weights, Indices, Specification

Risk Sharing Measure $\beta_{K}$

\begin{tabular}{|c|c|c|c|c|c|}
\hline Dependent variable & $\log \operatorname{SPEC}_{1}^{i}$ & $\log \operatorname{SPEC}_{1}^{i}$ & $\log \operatorname{SPEC}_{1}^{i}$ & $\operatorname{SPEC}_{2}^{i}$ & $\operatorname{SPEC}_{2}^{i}$ \\
\hline Weights & W1 & W1 & W2 & W1 & W1 \\
\hline Sample: & $\mathrm{A}$ & B & $\mathrm{A}$ & A & A \\
\hline Observations: & 158 & 149 & 158 & 158 & 158 \\
\hline $\mathrm{GDP}^{G}$ & $\begin{array}{l}-0.90 \\
(3.30)\end{array}$ & $\begin{array}{l}-0.90 \\
(3.00)\end{array}$ & $\begin{array}{l}-0.92 \\
(3.77)\end{array}$ & $\begin{array}{l}-0.20 \\
(3.74)\end{array}$ & $\begin{array}{l}-0.20 \\
(3.67)\end{array}$ \\
\hline$\left(\mathrm{GDP}^{G}\right)^{2}$ & $\begin{array}{c}0.04 \\
(3.32)\end{array}$ & $\begin{array}{c}0.04 \\
(2.99)\end{array}$ & $\begin{array}{c}0.04 \\
(3.79)\end{array}$ & $\begin{array}{c}0.01 \\
(3.81)\end{array}$ & $\begin{array}{c}0.01 \\
(3.73)\end{array}$ \\
\hline Population Density & $\begin{array}{c}0.81 \\
(2.77)\end{array}$ & $\begin{array}{c}0.94 \\
(3.17)\end{array}$ & $\begin{array}{c}0.81 \\
(2.49)\end{array}$ & $\begin{array}{c}0.29 \\
(5.79)\end{array}$ & $\begin{array}{c}0.28 \\
(5.69)\end{array}$ \\
\hline log Population & $\begin{array}{l}-0.13 \\
(2.20)\end{array}$ & $\begin{array}{l}-0.22 \\
(2.65)\end{array}$ & $\begin{array}{l}-0.13 \\
(2.10)\end{array}$ & $\begin{array}{l}-0.04 \\
(3.04)\end{array}$ & $\begin{array}{l}-0.03 \\
(2.87)\end{array}$ \\
\hline Manufacturing GDP Share & $\begin{array}{l}-0.38 \\
(0.40)\end{array}$ & $\begin{array}{l}-1.06 \\
(1.11)\end{array}$ & $\begin{array}{c}1.12 \\
(1.22)\end{array}$ & $\begin{array}{l}-0.32 \\
(2.02)\end{array}$ & $\begin{array}{c}-0.09 \\
(0.61)\end{array}$ \\
\hline$(\text { Man. GDP Share })^{*} \beta_{K}$ & $\begin{array}{c}4.65 \\
(3.40)\end{array}$ & $\begin{array}{c}5.32 \\
(3.11)\end{array}$ & - & $\begin{array}{c}0.60 \\
(2.57)\end{array}$ & - \\
\hline$\beta_{K}$ & - & - & $\begin{array}{c}1.07 \\
(3.14)\end{array}$ & - & $\begin{array}{c}0.13 \\
(2.26)\end{array}$ \\
\hline $\bar{R}^{2}$ & 0.72 & 0.67 & 0.74 & 0.40 & 0.40 \\
\hline
\end{tabular}

Notes: GDP ${ }^{G}$ : Gross domestic product per capita of risk sharing group G.

"Man. GDP Share" is the average (over the sample) of the share of manufacturing GDP in total GDP of each region.

W1: weighting by $\log$ of manufacturing GDP.

W2: weighting by $\log$ of population.

Sample A: Full sample minus Latin America.

Sample B: No Countries (full sample minus $O$ ECD and Latin America).

t-values in parentheses. 
Table 8: Instrumental Variables Regressions

Dependent variable-Specialization index $\log \mathrm{SPEC}_{1}^{i}$

\begin{tabular}{|c|c|c|c|c|c|c|}
\hline Sample & $\mathrm{A}$ & B & $\mathrm{A}$ & B & $\mathrm{A}$ & B \\
\hline Observations & 158 & 149 & 158 & 149 & 158 & 149 \\
\hline Instruments & $\mathrm{sr}$ & $\mathrm{sr}$ & $\mathrm{cr}$ & $\mathrm{cr}$ & FIRE & FIRE \\
\hline $\mathrm{GDP}^{G}$ & $\begin{array}{l}-0.90 \\
(3.41)\end{array}$ & $\begin{array}{l}-0.80 \\
(0.58)\end{array}$ & $\begin{array}{c}-0.90 \\
(3.33)\end{array}$ & $\begin{array}{l}-1.00 \\
(3.08)\end{array}$ & $\begin{array}{l}-1.00 \\
(3.50)\end{array}$ & $\begin{array}{l}-1.00 \\
(2.92)\end{array}$ \\
\hline$\left(\mathrm{GDP}^{G}\right)^{2}$ & $\begin{array}{c}0.04 \\
(3.42)\end{array}$ & $\begin{array}{c}0.04 \\
(0.74)\end{array}$ & $\begin{array}{c}0.04 \\
(3.35)\end{array}$ & $\begin{array}{c}0.04 \\
(3.07)\end{array}$ & $\begin{array}{c}0.04 \\
(3.37)\end{array}$ & $\begin{array}{c}0.04 \\
(2.91)\end{array}$ \\
\hline Population Density & $\begin{array}{c}0.80 \\
(2.80)\end{array}$ & $\begin{array}{c}0.71 \\
(0.52)\end{array}$ & $\begin{array}{c}0.83 \\
(2.80)\end{array}$ & $\begin{array}{c}0.97 \\
(3.21)\end{array}$ & $\begin{array}{c}0.86 \\
(2.84)\end{array}$ & $\begin{array}{c}1.00 \\
(3.12)\end{array}$ \\
\hline $\log$ Population & $\begin{array}{c}-0.11 \\
(1.90)\end{array}$ & $\begin{array}{l}-0.03 \\
(0.08)\end{array}$ & $\begin{array}{c}-0.11 \\
(1.69)\end{array}$ & $\begin{array}{l}-0.22 \\
(2.62)\end{array}$ & $\begin{array}{l}-0.10 \\
(1.53)\end{array}$ & $\begin{array}{c}-0.23 \\
(2.60)\end{array}$ \\
\hline Manufacturing GDP Share & $\begin{array}{c}1.52 \\
(1.71)\end{array}$ & $\begin{array}{c}1.29 \\
(0.32)\end{array}$ & $\begin{array}{c}1.61 \\
(1.74)\end{array}$ & $\begin{array}{c}1.25 \\
(1.44)\end{array}$ & $\begin{array}{c}1.71 \\
(1.81)\end{array}$ & $\begin{array}{c}1.32 \\
(1.47)\end{array}$ \\
\hline$\beta_{K}$ & $\begin{array}{c}1.18 \\
(3.55)\end{array}$ & $\begin{array}{c}1.45 \\
(0.71)\end{array}$ & $\begin{array}{c}1.33 \\
(2.41)\end{array}$ & $\begin{array}{c}1.42 \\
(2.93)\end{array}$ & $\begin{array}{c}1.38 \\
(3.62)\end{array}$ & $\begin{array}{c}1.49 \\
(3.19)\end{array}$ \\
\hline
\end{tabular}

Notes: cr: An index of creditor rights. sr: Four indicators of shareholder rights: one shareone vote (see, e.g., Zingales (1995)), proxy by mail allowed, cumulative voting/proportional representation, percentage of share capital needed to call an extraordinary shareholder meeting. FIRE: Finance, Insurance, Real Estate GDP as fraction of GDP $^{G}$ averaged over time for each group .

$\mathrm{GDP}^{G}$ : Gross domestic product per capita of risk sharing group G.

"Manufacturing GDP Share" is the average (over the sample) of the share of manufacturing GDP in total GDP of each region.

All variables in all regressions are weighted by $\log$ of manufacturing GDP.

Sample A: Full sample minus Latin America.

Sample B: No Countries (full sample minus OECD and Latin America).

t-values in parentheses. 
Table 9: Regression Results III

Risk Sharing Measure $\beta_{K+T}$

\begin{tabular}{|c|c|c|c|c|}
\hline Dependent variable & $\log \mathrm{SPEC}_{1}^{i}$ & $\log \mathrm{SPEC}_{1}^{i}$ & $\mathrm{SPEC}_{2}^{i}$ & $\mathrm{SPEC}_{2}^{i}$ \\
\hline $\mathrm{GDP}^{G}$ & $\begin{array}{l}-0.80 \\
(2.84)\end{array}$ & $\begin{array}{l}-0.80 \\
(2.78)\end{array}$ & $\begin{array}{l}-0.10 \\
(3.00)\end{array}$ & $\begin{array}{l}-0.10 \\
(2.95)\end{array}$ \\
\hline$\left(\mathrm{GDP}^{G}\right)^{2}$ & $\begin{array}{c}0.03 \\
(2.92)\end{array}$ & $\begin{array}{c}0.03 \\
(2.87)\end{array}$ & $\begin{array}{c}0.01 \\
(3.08)\end{array}$ & $\begin{array}{c}0.01 \\
(3.05)\end{array}$ \\
\hline Population Density & $\begin{array}{c}2.64 \\
(1.10)\end{array}$ & $\begin{array}{c}2.77 \\
(1.15)\end{array}$ & $\begin{array}{c}0.21 \\
(0.51)\end{array}$ & $\begin{array}{c}0.22 \\
(0.54)\end{array}$ \\
\hline log Population & $\begin{array}{l}-0.18 \\
(2.00)\end{array}$ & $\begin{array}{l}-0.20 \\
(2.42)\end{array}$ & $\begin{array}{l}-0.04 \\
(2.65)\end{array}$ & $\begin{array}{l}-0.04 \\
(2.91)\end{array}$ \\
\hline Manufacturing GDP Share & $\begin{array}{c}2.26 \\
(1.75)\end{array}$ & $\begin{array}{c}0.66 \\
(0.34)\end{array}$ & $\begin{array}{c}0.31 \\
(1.42)\end{array}$ & $\begin{array}{c}0.19 \\
(0.60)\end{array}$ \\
\hline$\left(\right.$ Man. GDP Share) ${ }^{*} \beta_{K+T}$ & - & $\begin{array}{c}2.84 \\
(1.33)\end{array}$ & - & $\begin{array}{c}0.22 \\
(0.60)\end{array}$ \\
\hline$\beta_{K+T}$ & $\begin{array}{c}0.86 \\
(1.82)\end{array}$ & - & $\begin{array}{c}0.07 \\
(0.93)\end{array}$ & - \\
\hline $\bar{R}^{2}$ & 0.77 & 0.76 & 0.25 & 0.27 \\
\hline
\end{tabular}

Notes: GDP ${ }^{G}$ : Gross domestic product per capita of risk sharing group G.

"Manufacturing GDP Share" is the average (over the sample) of the share of manufacturing GDP in total GDP of each region.

All variables in all regressions are weighted by $\log$ of manufacturing GDP.

Sample F is used for all regressions: Full sample minus Latin America and Japan. t-values in parentheses. 
Table 10: Regression Results IV

Risk Sharing Measure $\beta_{K+T+C}$

\begin{tabular}{|c|c|c|}
\hline Dependent variable & $\log \mathrm{SPEC}_{1}^{i}$ & $\operatorname{SPEC}_{2}^{i}$ \\
\hline Sample: & A & A \\
\hline Observations: & 158 & 158 \\
\hline $\mathrm{GDP}^{G}$ & $\begin{array}{l}-0.60 \\
(2.45)\end{array}$ & $\begin{array}{l}-0.10 \\
(3.14)\end{array}$ \\
\hline$\left(\mathrm{GDP}^{G}\right)^{2}$ & $\begin{array}{c}0.03 \\
(2.49)\end{array}$ & $\begin{array}{c}0.01 \\
(3.20)\end{array}$ \\
\hline Population Density & $\begin{array}{c}0.56 \\
(1.72)\end{array}$ & $\begin{array}{c}0.27 \\
(4.88)\end{array}$ \\
\hline log Population & $\begin{array}{l}-0.15 \\
(1.83)\end{array}$ & $\begin{array}{l}-0.04 \\
(2.82)\end{array}$ \\
\hline Manufacturing GDP Share & $\begin{array}{c}0.74 \\
(0.79)\end{array}$ & $\begin{array}{c}-0.15 \\
(0.97)\end{array}$ \\
\hline$\beta_{K+C+T}$ & $\begin{array}{c}0.19 \\
(0.32)\end{array}$ & $\begin{array}{c}-0.03 \\
(0.34)\end{array}$ \\
\hline $\bar{R}^{2}$ & 0.70 & 0.38 \\
\hline
\end{tabular}

Notes: GDP ${ }^{G}$ : Gross domestic product per capita of risk sharing group G.

"Manufacturing GDP Share" is the average (over the sample) of the share of manufacturing GDP in total GDP of each region.

All variables in all regressions are weighted by log of manufacturing GDP. Sample A: Full sample minus Latin America.

t-values in parentheses. 
Figure 1: Specialization Indices
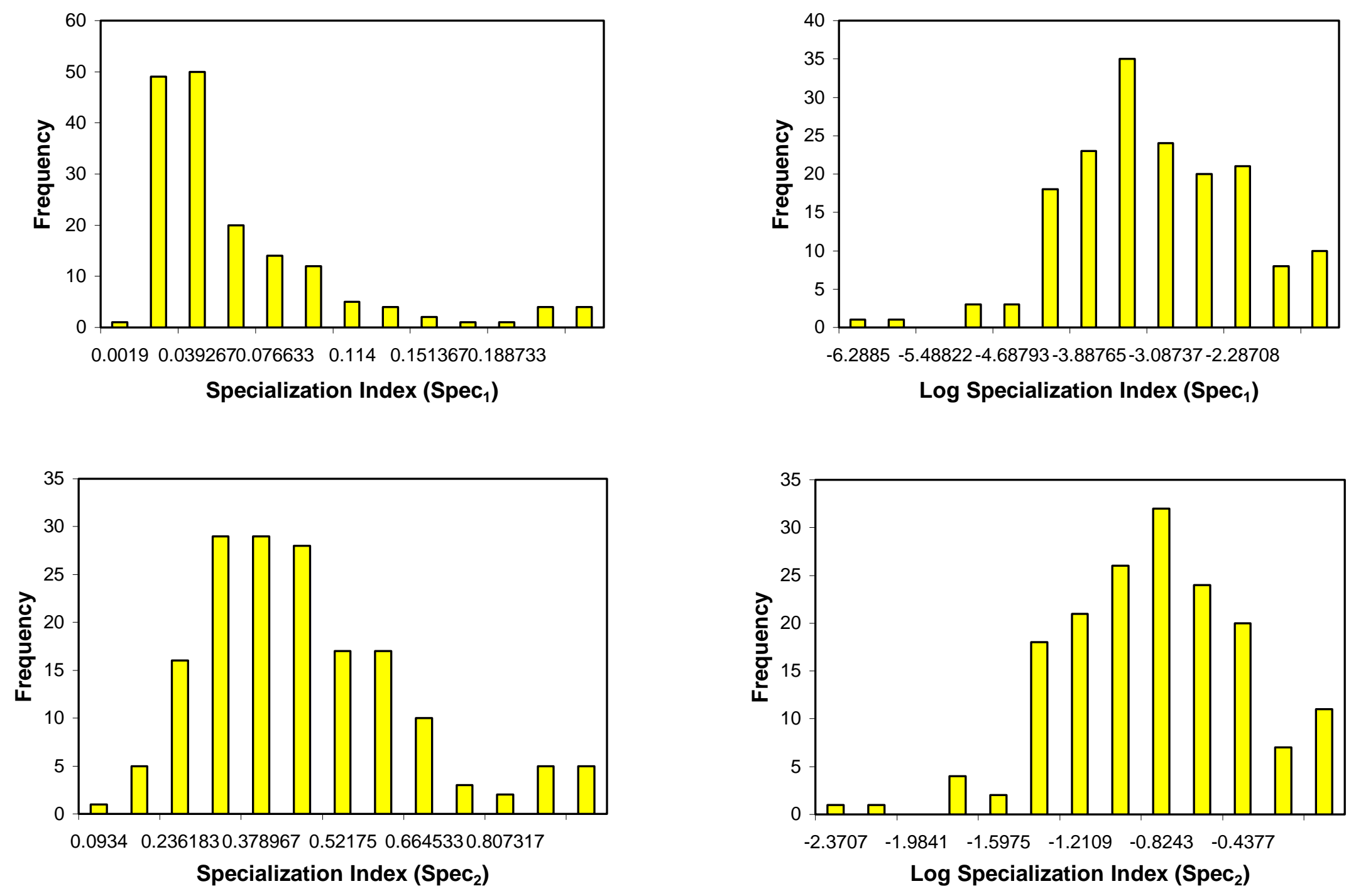
Figure 2: Specialization vs. Risk Sharing

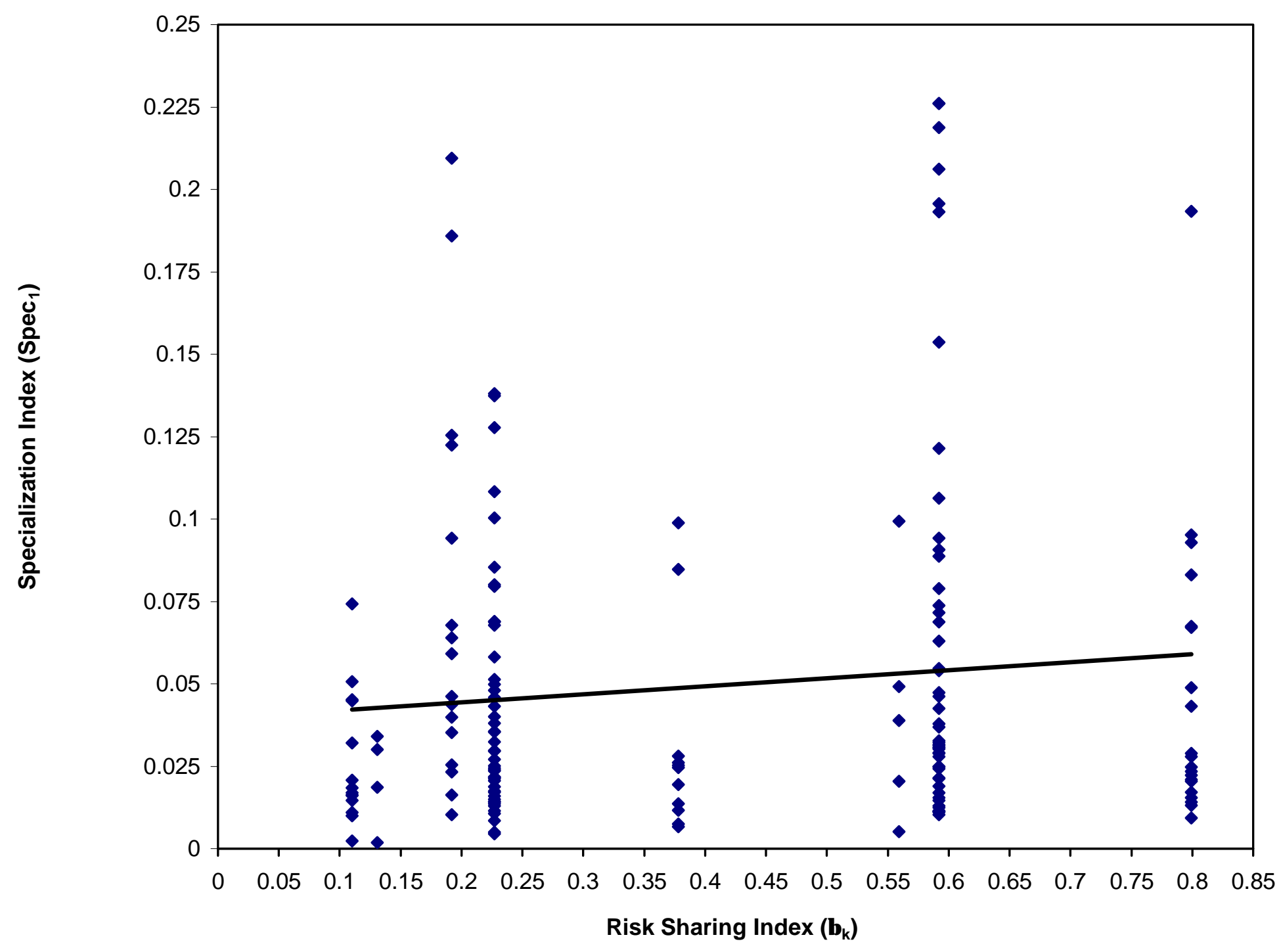


Figure 3: Specialization vs. Risk Sharing

(Controlled for the effect of other regressors)

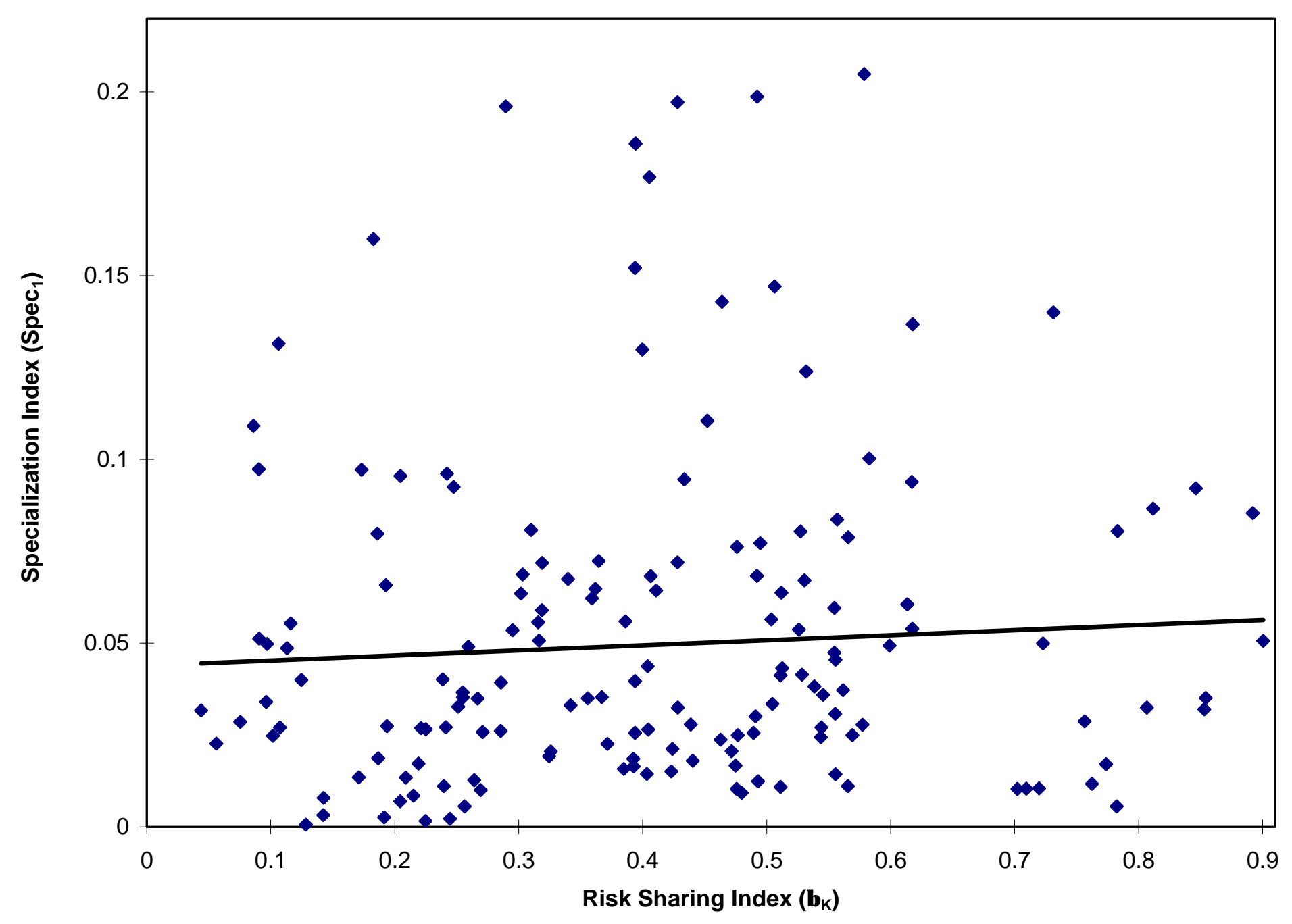

